\title{
ACTIVISTS AND INCUMBENTS STRUCTURING CHANGE: THE INTERPLAY OF AGENCY, CULTURE, AND NETWORKS IN FIELD EVOLUTION
}

\author{
JAKOMIIN VAN WIJK \\ Maastricht School of Management \\ WOUTER STAM \\ Hong Kong University of Science and Technology \\ TOM ELFRING \\ VU University Amsterdam \\ CHARI.ENE ZIETSMA \\ York University \\ FRANK DEN HOND \\ Hanken School of Economics \\ VU University Amsterdam
}

\begin{abstract}
We examine organizational held change instigated by activists. Contrary to existing views emphasizing incumhent resistance, we suggest that collaboration between incumbents and challenger movements may emerge when a movement's culturaI and relational fabric becomes moderately structured, creating threats and market opportunities but remaining permeahle to external influence. We also elucidate how lead incumbents' attempts at movement cooptation may be deflected through distributed brokerage. The resulting confluence of cultural and relational "structuration" between movement and field accelerates the pace but dilutes the radicalness of institutional innovation, ensuring ongoing, incremental field change. Overall, this article contributes to the emergent literature on field dynamics by uncovering the evolution and outcomes of collaborative work at the intersection of social movements and incumbent fields.
\end{abstract}

The agentic turn in institutional theory has marked a shift in attention from the isomorphic fnrces that stabilize organizational fields toward consideratiun of the dynamic processes by which fields form and transform (Dacin, Coodsteir, \& Scott, 2002). Following oarly work that focused on

We would like to thank past chicf editor Dunne Ireland and the three anonymous reviewers for their excellent comments and suggestions. The first author also thankfuily acknowledges Roy Suddaby, Royston Grecnwood, Marvin Washington, and all other members of the Departmonl of Strategic Management and Organization at the Alberta School of Business for the inspiring discussions on a draft during her visiting doctoral schnarship. We are also indebted to Anoop Madluk. Tom Lawrence, and Zhi Huang for their feedback on drafts. Of contse. any errors are our responsibility. exogenous jolts (Mever, 1982) and institıtional ontrepreneurs (DiMaggio, 1988), lield-level change has been increasingly characterized as the outcoine of collective action involving social movemonts (Hargrave \& van de Ven, 2006; Rao, Morrißl, \& Zald, 2000; Schneiberg \& 1.ounsbury, 2008). However, the connection between field change and collective action is not straightforward. In mature fields, for example, the ability of challenger movements to affect change is often severely undernined as powerful incumbents forcefully defend the field's status quo (Hensmans, 2003; Maguire \& Hardy, 2009; Zietsma \& Lawrence. 2010). At the same time, Fligstein has suggosted that "occasionolly, incumbents might defect to the side of challengers and help produce change in the field" (2001: 118, emphasis added).

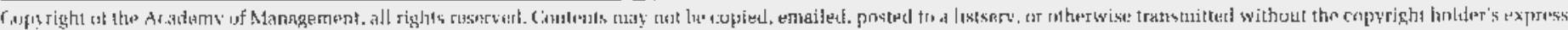

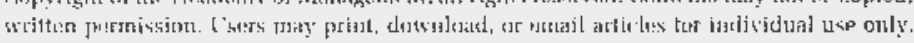


Despite the insight that collaborative work between activists and field incumbents may form an implortont catalyst for field evolution. studies of this collaborative action model are still scarce (O'Mahuny \& Bechky, 2008). Addressing this knowledge gap is important for the alvancemont of current understandings in field dvnamics, as collaborations are "potentially important context[s] for the process of structuration upon which institutional fields depend" (Phillips. Lawrence, \& Hardy, 2000: 23). Accordingly, the present article asks. How does collaborative work between activists and field incumbents emerge and affect the organizational field under challenge?

To answer this rosearcli question, we examined the sustainable tourism movement in the Dutch outbound tour operations field from 1980 to 2005 , which is an instructive site of collaboration between activists and field incumbents. This collaborative work, which is evident in the launch of a multistakeholder platform, joint projects, and the development of a shared moaning system. has resulted in field change. In the early 19g0s. sustainable tourism was a fringe outsider movement that was of little interest to tour operators. By the mid2000s, however, nearly all tour operators had cornmitted to a sustainability framework, and major firms worked on reveloping sustainable tuur parkages, despite the absence of either a strong markel pull or sigrificant government pressure. Nevertheless. the changes werc loss radical than the movement initially envisioned.

Our findings led us to develop a process mndel of actjvist-instigated fiold change, providing key theoretical insights. Whereas previous studics have fucused on opportunity structures external to movements to explain movernent efficacy in affecting fields, wo introduce the concept of "movement permeability" to emphasize that the opportunity structure of the movement itself is critical for explaining the emergence of collaborative work. Furthermore. we advance the extant understanding of cooptation by uncovering how attompts by lield eljtes to coupt the movement can be deflected when multiple brokers connect actors and ideas across movement and field, activating a process of mutual cooplation. Finally, we offer new insights into how network outcomes are culturally constituted. noting the combined influence of a cultural template and a small-world network on the pace, radicalness, and persistence of innovative action. In so doing. wo contribute to recont theory on the dynamicss of small-world networks.

\section{THEORETICAL ORIENTATION}

\section{Organizational Fields and Challenger Movements}

The concept of organizational field refers to "a community of urganizations that partakes of a common meaning system and whose participants interact more frequently and fatefully with one another than with actors outside the field" (Scott, 2001: 84). Although isomorphic forces stabilize organizational fields (DiMaggio \& Powell, 1983), institutional scholars increasingly examine how fields change (Dacin et al., 2002). While exngenous jolts (Meyer, 1982) and institutiunal entrepreneurs (see Battilana, Leca, and Boxenbaum [2009] for a review] have been found to contrihute to change. field-level change has also been attributed to collective action by social muvements that challenge a field's prevailing institutions (Hargrave \& vin de Ven, 2006; Rao et al., 2000: Schneiberg \& Lounsbury, 2008). Wo distinguish three main pathways for movernents to affect fields: a contlic:tual approach focused on crcating threats for incumbents, a market approach focused on creating farorable conditions for ontrepreneurs, and a coliaborative approach focused on affecting organizational ficlds from the inside.

In the conflictual approach to activism, inowements pressure third parties to coerce changes in organizational ficlds. For example, Schneiberg and Soule (2005) found that anticorporate movements convinced governments to disrupt insurance mirrkels through anticompact laws. Social movononts have also mobilized consumers or industrial buyers to pressure firms to change practices (e.g.. Bartley, 2010; Frooman, 1999; Zietsma \& Lawrence, 2010). Movements using a conflictual approach emphasize a strong collective artion frame (Benford * Snow, 2000) to mobilize resources for contestation and explnit political opportunity structures (McArlam, McCarthy, \& Zald, 1996). Yet incumbent firms often countermobilize (Hensmans, 2003) and undertake "delensive institutional work" (Maguire \& Harely, 2009), turning organizational fields into "institutional war" zones (Hoffman, 1999: 352).

Second, social movements may create market upportunities for entrepreneurial actors by stimulating new market demands or changes in industry conditions (King \& Pearce, 2010; Rao. 2009]. For example, environmental movenents have ben crodited with creating the regulatory conditions that encouraged wirzd-power start-ups (Sine \& Lee, 2009) and stimulating market demand for grossfed beef and dairy products [Weber, Hoinze, \& 
deSoucey, 2008). However, these opportunities often involve niche markets; wind power and grassfed beef, for example, accounted for less than one percent of total sales in their respective industries.

Third, social movements may take a collabora tive approach, working directly with field members to help instigate change. In such instances, movemonts "enter into and operate within fields as institutional forces" (Schneiberg \& Lounsbury, 2008: 655. emphasis added). Lounsbury and colleagues (Lounsbury, 2001, 2005; Lounsbury, Ventresca, \& Hirsrb. 2003), for example, found that recycling activists initially took a conflictual approach to the waste industry but later forged ties with industry representatives, negotiated public policy changes and promoled the for-profit version of recycling favored by the industry. This collaborative action model holds promise for social movements when state and market actors are unwilling or unable to act as third-party cnforcers, and when the market demand for novement-related innovatinns is weak, or when the movement wants to karget more than just a small niche. However, research on collaboration betwren challengers and incumbents is scant (O'Mahony \& Bechky, 2008).

Challenger movements may face difficulties when attempting to transform established fields by working with field incumbents. Mohilizing and maintaining a collective can be challenging when disparate actors have divergont interests, backgrnunds, and resources (Fligstoin. 2001; Garud, Jaiı. \& Kumaraswamy, 2002). It nuay also he difficult to motivate field nombers to collahorate. Typically, movements' networks are not connected to those of field menhers, and their value frames tend to conflict, providing a limited hase for collaboration. Moreover, movements lack access to the institutional maintenance mechanisms that reinforce extant ideas and practices in the field. These mechanisms are often controlled by elite, institutionally enhedded incumbents (Greenwoud \& Suddaby. 2006) and ficld-governing horlies like trade and professional associations (Greenwood. Suddaby, \& Hinings, 2002), which are either unable or unwilling to engage in challenger movements. How, then, do challenger movements succeed in mobilizing collaborative action? And, following O'Mahony and Bechky, what outcomes are produced when "challenging and defending parties meot at the table inside"? (2008: 452). These questions lie at the heart of nrganizational field theory, as they draw our attention to the relational and cultural "strus;uration" of orgarizational fields (Phillips et a1., 2000].

\section{Relational and Cultural Structuration in Field Evolution}

For challonger movements and field incumbents to collaborate, relational and cultural structuration must occur; members of movements and fields must interact and communicate intensively, recognize that they are part of an institutional change project and develop shared norms, belicfs, and frames of reference to guide their interactions (DiMaggio \& Powell, 1983; Scott, 2001). Relational structures, or networks, emerge among actors who mobilize resourcos and forge relationships with supporters of their desired change projects (Battilana et al., 2009; Diani \& McAdam, 2003; Hargrave \& van de Ven, 2006]. Network relationships function both as pipes through which resources and practices are diffused and as prisms that facilitate sense-making and the development of shared meaning among actors (Podolny, 2001). Thus, networks are not only critical resources for coordination among disparate actors but are also important for the developinent of cultural structures. Interacting actors shape shared meaning systems out of "heterogeneuus hits of culture" (Weber \& Dacin, 2011: 289), including "meanings. local practices, discourse, repertoires, and norms" (Pachucki \& Breiger, 2010: 206) that are initially created by independent actors.

The nascent but growing literature on "whole" networks (Provan, Fish, \& Sydow, 2007) offers valuable insights into the network properties that enable or constrain collaborative action and innovation in ficlds. At the micro level, coordination can be achieved hy network cliques, which are defined as groups of actors who form more colyesive ties with one another than with other neiwork members. Clique members tend to develop strong. overlapping ties that engender collaboration, trust. norms of reciprocity and social control (Provan \& Sebastian, 1998; Uzzi, 1997). Thus, hy mobilizing local actors around novel projects, cliques can be important generative structures for innovative action (Ohstfeld, 2005). Yet, the norms, languages. and ideas of clique members tend to converge over time, suggesting that cliques might also limit innovation.

At the macro level, the formation of bridging ties between previously unconnected cliques may foster coordinated innovative action among actors by 
enabling creative material to quickly flow across distinct clusters. Network structures featuring both high levels of hom clustering and short global path lengths between the r:lusters have been termed "small worlds" (Watts, 1999). Research on small worlds suggests that they are common, robust structures that speed diverse lows of resources, ideas, norms, and practices amnng network participants (Baldassarri \& Diani. 2007: Kogut \& Walker, 2001: Uzzi \& Spiro. 2005). However. Gulati, Sytrh, and Tatarymowicz (2012) have suggested that snill worlds are only tomporary centers of gravity within fields: they may fiagment and decay over time as imnovation opportunities dry up. Thus, the prucesses by which diverse actors and their ideas. norms. and practices intersect and create connections within and between social groups have im portant implications for collaborative work and innovative action in fields, although they remain understudied. Our research focuses on such dynamics hy examining the interplay of cultural and relational structures and agency at the intersection of a challenger movement and an established field.

\section{SUSTAINABLE TOURISM AND DUTCH OUTBOIIND TOUR OPERATIONS}

Congruent with the first scicntific publiriations on the negative imparts of tourism (e.g., Krippendorf. 1975; Turner \& Ash, 1975] and the hroaler discourse on sustainable development (e.g. WCED, 1987), the issue of sustainable tourism emerged in the 1970 s and 1980 s. broadly comprised of two subdiscourses. The first, inspired by World Conservation Strategy, the International Union for Conservation of Nature's (IUCN's) 1980 report. focused on the environmental impacts of tourism. The second, formalized by the Excumenical Coalition on Third World Tourism in 1982 and its European spin-off organizatiun in 1984 . focused on the sociocultural and economic inpacts of mass tourism on comnunities in developing countries (O'Grady, 1981). Both subdiscourses prompted numerous actions to green the industry and devolop alternative forms of tourism, such as ecotouristn and community-based tourism.

In the Netherlands, fringe outsider groups critirized outbound tour operators in the early 1980 s for neglecting sustainability issues. The outhound tour operations field, which energed in the 1920s. features both elite and peripheral firms. The field is governed by the Association of Travel Agents and Tour Operators (ANVR), founded in 1966. Out- bound tour operators bulk-purcliase tourism services, such as transportation and accommodations. rebrand them as packaged vacations and sell them to cnnsumers. As intermediaries in the supply chain, tour operators are important charpe agents for making tourisn mora sustainable. Initially, the campaigr for sustainable tonrisun failed to resonate within the outbound tour uperations ficld. By the mid-200us, however, several key changes indicatod that the field was engaging with the issuc.

Drawing on indicators for ficlu evolution as found in Scott, Deschenes. Hopkins, Nuwman, and McLaughin (2006), the changes are as follows. First, a frontrunner group of tour operators emerged that made sustaindbility part of their commercial business logic. Their rolu shifter from merely selling vacations to being socially and murally ar:countable for tourism's impacts. T'able 1 presents examples of measures taken by tnur operalors. Because environmentally friendly or socially responsible moasures only form elements of mainstream vacation packages, we are unable to provirle figures regarding the market penetration of "sustainable tour packages." However. it is relevant to note that the firms engaging in voluntary sustainable tourism projects and the multistakehnlder platform not only include special ist firms serving niche inarkets but also elite tour operators that serve the mainstrean organized outbound vacation market, with a combined market share of nearly 40 percent in 2009. Second, high-profile conferences, public events, and publicatiams have emerged that are designed to stimulato discussion on this issue. These forums include an annual national conference on sustainable tourism (the Groeneveld Conference) and regular side-ovents at vacation trade fairs. Third, sustainable tourism became a membership criterion for the ANVR tadu association in 2003, when the Product Oricnted Environnental Management Scheme (POLMS) was inlroduced. ${ }^{1}$ ANVR tour operators became obliged to drafl a policy statement and actiun plan, appoint a qualificd POEMS coordinator, and exclude any unethical tourism products from their range. The POLMS certificete is awarded by an independent foundation launched by ANVR. This is a remarkable development, as most sustainable tourism initiatives by the tourism industry had been voluntary (Tepelus, 2005: WTO/OMT, 2002). To ust: ANVR's inde-

\footnotetext{
${ }^{3}$ POEMS was replactel by a sinulas scheme in 2008, which remained enforced by ANVR in 2012.
} 
TABLE 1

Examples of Sustainable Tourism Measures by Dutch Outhound Tour Operators

\begin{tabular}{|c|c|}
\hline Level of Action & Sustainable Tourism Initiatives \\
\hline Orgonization & 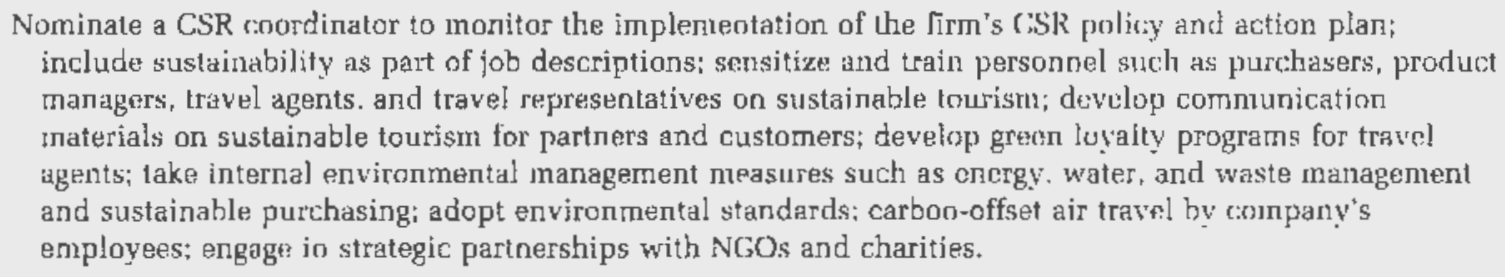 \\
\hline \multicolumn{2}{|l|}{ Supply rhain } \\
\hline 'l'ralsportation & 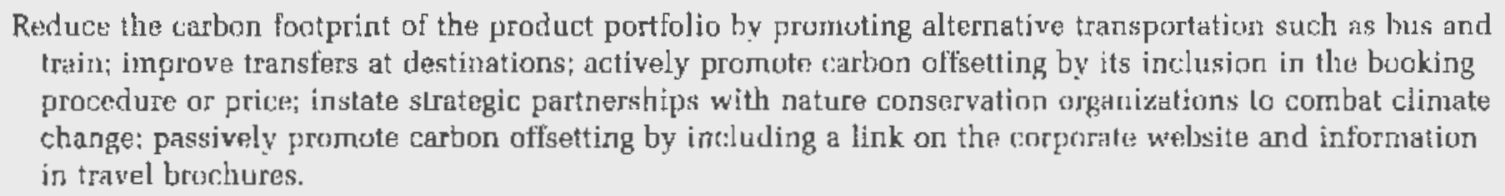 \\
\hline Accominodation & $\begin{array}{l}\text { Pyterontially select environmentally cortified accommodations, which are promuted in the travel brochures } \\
\text { through a separate logo; oblige all contracted hoteliers to subnit information on their sustainability } \\
\text { pertornance through a third party's central industry database; train prodnct managers and purchasers on } \\
\text { ststatinabily criteria to include these in the negotiations with hoteliers; include ciauses on sustainable } \\
\text { tourism in the contracts with hoteliers. }\end{array}$ \\
\hline Leisure & 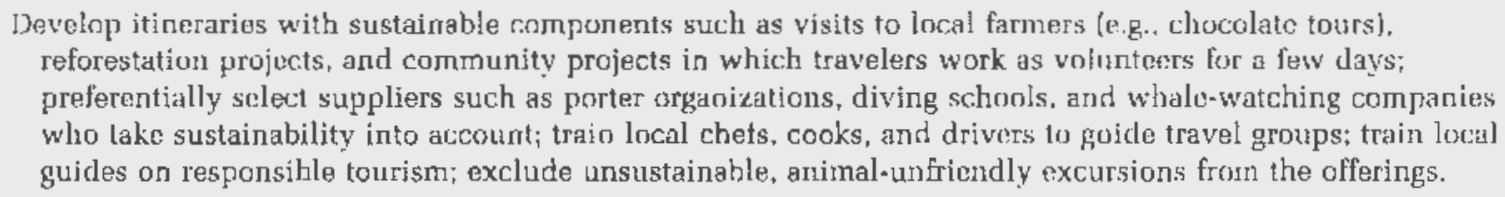 \\
\hline Destinotion & 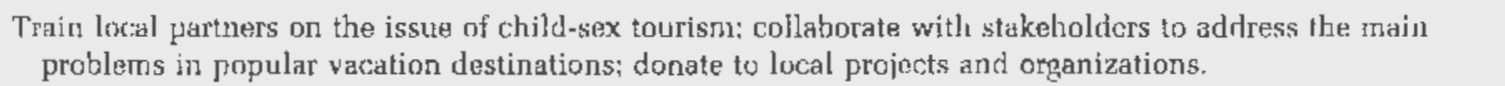 \\
\hline
\end{tabular}

pendent brand, which is highly valued by consumers as a quality hallmark, most tour operators join ANVR. In 2010, voluntary membership included 213 tour operators, representing approximately 85-90 percent of the organized vacation market. Fourth, new field-level organizations dedicated to sustainable tourism have emerged. For instance, in 1996, a multistakeholder platform, Vereniging voor Duurzaam Uitgaand Toerisme (IDUT), the Association for Sustainable Outhound Tourism, was latunched to spearhead the transition to sustainable tourism, and it became an independent foundation in 2009. ANVR chairs the platform. IDUT hosts over 25 organizations, including representatives of industry. government, NGOs, and education; publishes quarterly newsletters; and annually orgaoizes the Groeneveld Conference. Fifth, monitoring of sustainable tourisn achievements, consumer demand for sustainable tourism, and the carbon footprint of Dutch citizens' vacations bas begun. Finally, sustainable tourism has been included in the curricula of various tourism schools, and a training program for tour uperators was launched in 2002. In sum, the fringe sustainable tourism movement has been able to gain a fouthold in the outbound tour operations field, as evidenced by tuur operators' increased engagement with sustainability issues. Nevertheless, a "profound transformation" of the field (Dacin et al., 2002: 50) has not occurred. Rather, the changes exemplify "piecemeal changes ... in the constant playing of the game as cnnditions change within a field or between fields" (Fligstein \& McAdam, 2011: 21). The next step is to examine how this incremental change came about.

\section{METHODS}

We used an explorative single case study that combined qualitative data analysis with quantitative social network analysis, enabling us to capture "a more complete, holistic, and contextual portrayal of the unit(s) under study" (Jick, 1979: 603). Hybrid research designs are particularly useful when exploring new questions that are pertinent to theory building (Edmondson \& McManus, 2007). As this is one of the first studies to examine the recursive relationship among agency, culture, and networks during a collahorative change process. explorative research mothods were well suited to our purposes. 


\section{Data Sources}

Having defined the field of outbound tom operations geographically (cf. Greenwood \& Suddahy. 2006), we collectud data on the events and artors associated with susiainalule tourism in the Netherlands, ranging from the first reported events in the 1980 s throtgh 2005, when all ANVR tour operators hed implemented the POEMS schene. Although formal data collection ran from 2004 to 2006 , we continued to monitor field devolopinents up until January 2010 .

this research is based on interviews, doctunents, public sources, and fieldwork. Wo conducted 22 semistructured interviews with individuals involvod in the change process. Respondent selection was based on references to individuals and affiliated organizitions in reports, snowball sampling techniques, and in-depth knowledge of the field (the first anthor has frequently attended industry trade fairs and sustainable tourism conferences since 1999). The interviow protocol focused on movement issues. actors, activities, and outcomes and was custumized for each interviewre to best capture his or har role in the change process. Some of the respondents were interviewed nore than once. Intervinws were recorded, transcribed verbatim, and returned to the respondent for additional conments. These data wore supplementod with 12 verbally transcribed interviews on the same change process that were collected in another research project but reviewed by the first author. Wo also conducted numorous informal interviews at trade frirs and conferenucs:

Documents. such is fïm histuries. policy documents, resturch reports, press releases, confercnce proceedings, newsletters, and jutirnal articles, were also amialyzod. Because trade urganizations are known for thoir substantial data recording (Greenwood ot al., 2002), adelitional materials were collected from $N$ NVk, including minutes from thes IDLIT platform and industry neetings, correspondence, imminl reports, policy papers, magazines. and brochures. The procectings of the annual Groeneveld Conforences and ANVR's magazine provided rich longitudinal data on tho issues, innuvations, and participants in the change process. Public sources, such as wobsites, wob archives, and hibliogruphic and newspaper databases. wore used for conss-verification. Intonsive in-situ and in-vivo fieldwork was conducted by the first author. who attended the Groeneveld Conferences, vacation trates fairs, and quarterly meetings of the IDL'1' platform as well as over a dozen workshops and meetings on sustainalule tourism betweon Docemiber 2004 and kanuary 2007. A field diary was kept throughout this period.

\section{Data Analysis}

The data analysis comprised five stages. We used the identification of events (Stage 1) to create? affi iation network databases (Stage 2) and draft a case chronology (Stage 3). W0 thon examined the multilevel nature of institutional agency through the cluange process by intensively corrobonting iusights from tho analysis of qualitative and social network data (Stages 4 and 5).

In the lirst stago. we identified ovents as key ubservational units (van de Ven \& Poole. 2002), adopting a process-centric: approach to agoncy (Hardy \& Maguire, 2008; l,angley. 2007). We clefine: events as manifestutions of individial and organizational actors' actions thut potentially contribute to the croation of now institutions or the transformation of existing ones in an organizational fich. We used the exents suggested in the literature as proxies for institutional agency as our analyticial categories for a careful examination of the interview transcripts. ${ }^{2}$ Aided by $\Lambda$ l'L $A S i t i$ software, we found that indivicluals working to create or abange institutions in outbound lour nperations engaged in five types of wonts (Table 2): (1) delivering keynote? speeches at confermcess. (2) convoning and bhairing workshops at conferences. (3) initiating projects on sustainable tourism targeter at consuners and vacation providers, (4) launching new arganizations to develnp and promote sustainable practices. and (5) writing publications un related topics.

The main prenine of affiliation network analusis is that social ties between actors develop un the basis of joint involvement in conmon events (Wassornua \& Faust, 1994). Accordingly, we identified all actors that were agentic in sustainable tourism through the events listed in 'Table 2. In the second

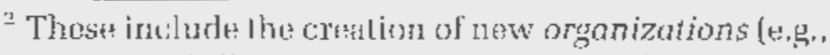
Lawrence \& Phillijs, 200-4). start-up of (pilot) projocets (e.g. DiMiggio, 1991), fuembership on advisory commitlees or hoards of dinectors (n.g. Greenuroud t: al.. 2002). detivering koyncte spueches it conftronch [0.g. Gurud \& Rappi. 1944). giving roirses and fertures (a.s. Sxjenova, Mazze, \& Plamo!lis. 2007]. theorizing aloum change in publicofions such is annual roports and advertisoments (e.g. Munic \& Phillips, 2005). ind organizing or

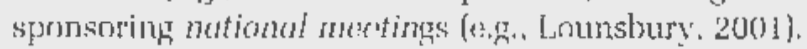


TABLE 2

Events as Manifestations of Institutional Agency

\begin{tabular}{|c|c|}
\hline Event Type & Illustrative Quotations \\
\hline Conference & 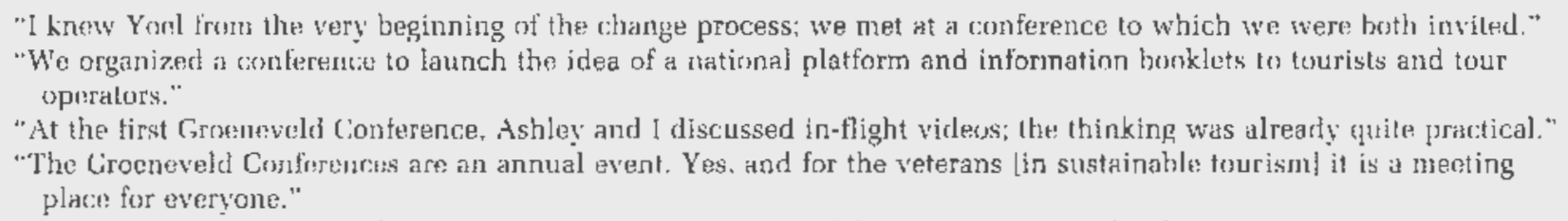 \\
\hline Project & 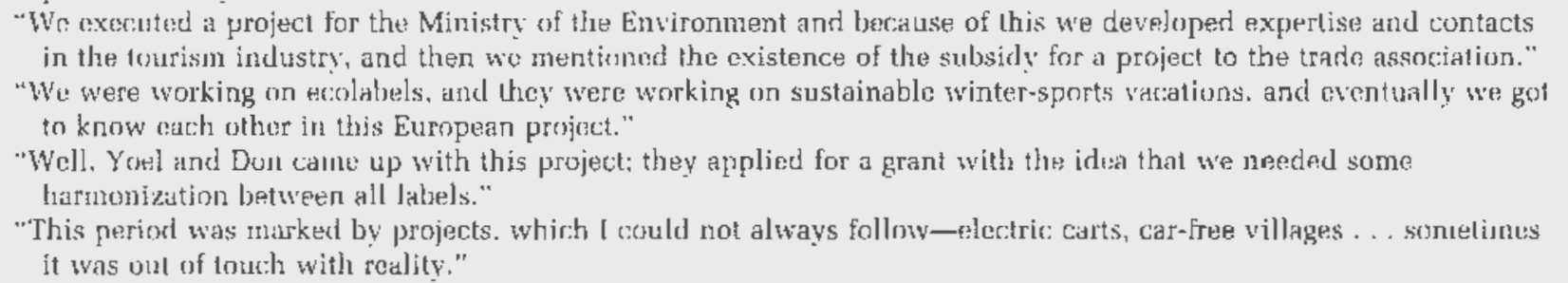 \\
\hline Oryanization & 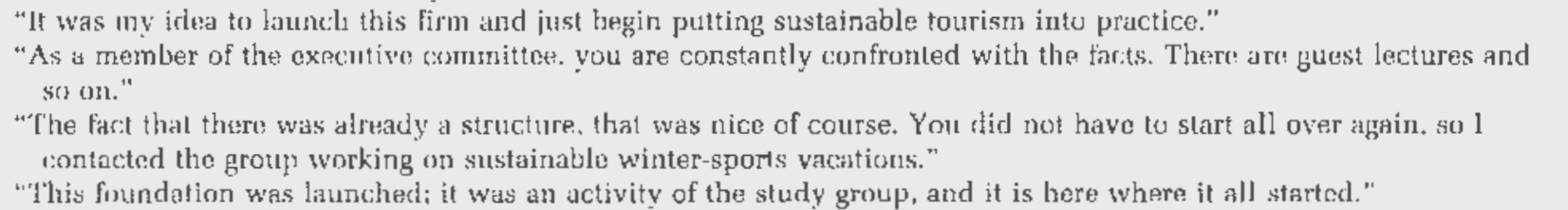 \\
\hline Publication & 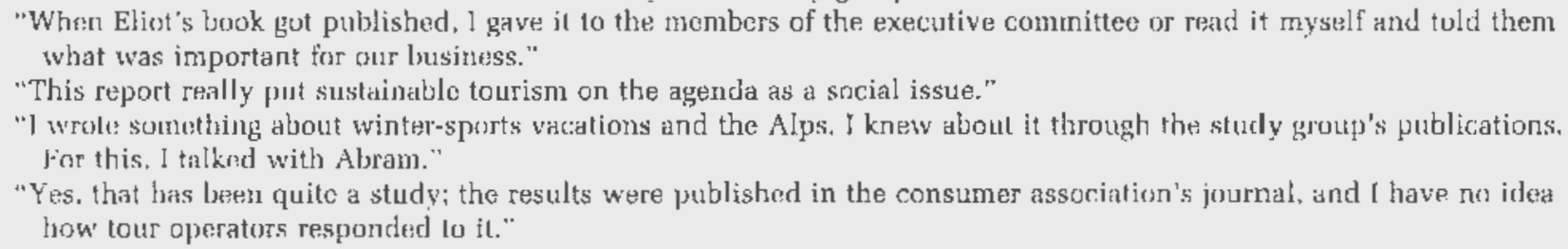 \\
\hline
\end{tabular}

stage, we tabulated the data by linking each event to its affiliated individuals. Following Ring and van de Ven (1994), our data also included these individuals" organizational affiliations." We consulted several data sources to develop this database (Appendix A, available from the first author, provides an overview), In total, we found 237 unique persons affiliated with at least one of the 233 events wo recorded. ${ }^{4}$ In the third stage, we drafted a case chronology (Table 3) and then ascertained the extent to which the outbound tour operations field had been transformed, also looking into changes at the firm level (Table t).

The fourth stage involved using socinmetric techniques to examine institutional agency at threc levels of analysis: the glohal network. clique, and individual actor. First, we studied the movement's

\footnotetext{
${ }^{3}$ Some events were difticult to attribute to individuals (o.g. a govmmment ministry's autivities). In such instances. we only recorded the organization's affiliation with the event.

${ }^{4}$ Thase figures thus only list the initiators of challengm activities. If we took conferences participation inio ancount, the movemont comprisnd 1,195 unique persons.
}

overall network by creating two-mode affiliation networks (Faust, 1997) that linked individuals based on their joint participation in events. We grouped conference keynotes, workshops, and publications together as theorizer activities and classified the founding of organizations and projects as founder activities. Accordingly, for each year. we created three separate two-mode data matrices: a founder network matrix $\left(N_{\text {ackurs }}=68, N_{\text {uxwils }}=82\right)$, a theorizer network matrix $\left(N_{\text {atetors }}-202, N_{\text {wernts }}-\right.$ $151)$ and a morged network matrix $\left(N_{\text {artists }}=237\right.$. $N_{\text {ovents: }}=233$ ) that combined both. In these matrices, $X_{i j}=1$ when actor $i$ is affiliated with event $j$, and $X_{i j}=0$ otherwise.

As in prior work (Rowley, Greve, Rao, Baum, \& Shipilov, 2005), we used a five-year moving window to construct affiliation network matrices. Our starting networks were based on all actor-event affiliations observed in 1995. Working forward in time, we added new events and actors to the networks each year. If an indjvidual remained inactive (i.e., was not affiliated with any event) for five years, that individual and his or her links were removed in year five. We reran the analyses using 
TABLE 3

Overview of the Main Incidents in the Change Prucess toward Sustainable Tourism

\begin{tabular}{|c|c|}
\hline Year & Main Even! \\
\hline 19692 & Founding of the Envinommental Study Group on the Mps \\
\hline 14hat & linunding of the Tourisn and the Third World Foundation \\
\hline 1989 & l'ublication of the tuxtbnok Tourism: Fraternizalion or Degentration?' \\
\hline 1491 & Fonoding of the Netherlands Alpine platform (NAP) \\
\hline \multirow[t]{3}{*}{ †992 } & Acloption of thes ANVK Erivirommental Code of Conduct \\
\hline & Demonstration by emvirommentalists against the growlly of tlight vacations \\
\hline & Lutuch of unolabel for outdoor activities \\
\hline 1994 & I'ublicatiun of the Advisory Cuuncit for Nature Polluy's report \\
\hline \multirow[t]{3}{*}{1995} & First Giroenteveld Conferunce \\
\hline & ANVR policy doc:ument on sustainable tourism I \\
\hline & Fommet launcly of the ANVK Executive Committe on Sitstainable Tourism \\
\hline \multirow[t]{3}{*}{1990} & Founding of the [DUT" platforn and its scound Groenemeld Conference \\
\hline & Adrption of the rNVK Code of Conduct against child-sox hurism \\
\hline & Latutuch of the roilunlary light tax \\
\hline \multirow[t]{2}{*}{1998} & 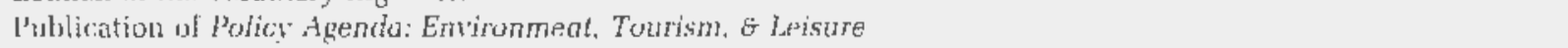 \\
\hline & 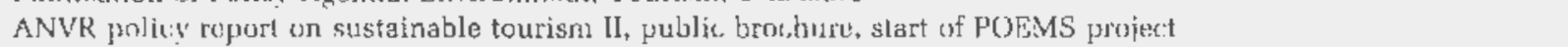 \\
\hline \multirow[t]{4}{*}{1999} & 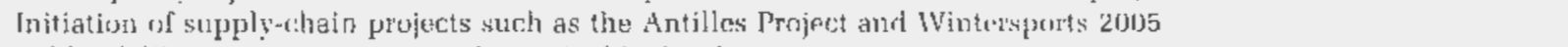 \\
\hline & Public deliberation on tuurisn and sustainable developnent \\
\hline & Gruesuweld Conference becomes an annual exent (jost-199s) \\
\hline & Developnent of the firsl carbon-offsetting scheme \\
\hline \multirow[t]{4}{*}{2000} & 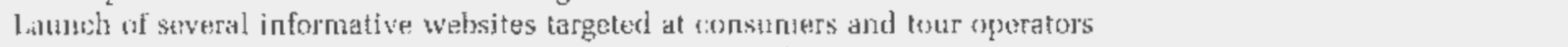 \\
\hline & 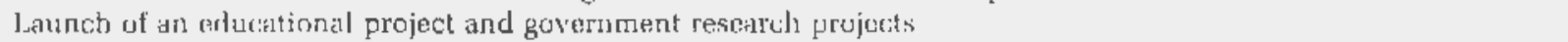 \\
\hline & Publit alion of AVVR's public brochure on CSR in the travel and tourista industry \\
\hline & ANVR's POFNS accepted as a merthership reterion \\
\hline 2001 & Lumsty of a European project on ecolabeling \\
\hline \multirow[t]{3}{*}{$200:$} & Fannch of vecilion packages thal include visits to nialional parks \\
\hline & Laundty of ANVR's PUEMS course \\
\hline & Campaign agratost tour operators ojerating in Burma \\
\hline \multirow[t]{3}{*}{$2(10)$} & 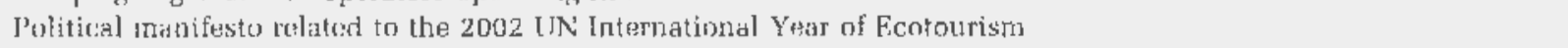 \\
\hline & Latulach of a new carbon-offsotting schente \\
\hline & $\begin{array}{l}\text { First formal portntrships botween tour uporators and NGOs un anture ronservalion and the prevention of child-sex } \\
\text { tourism }\end{array}$ \\
\hline \multirow[t]{2}{*}{2004} & 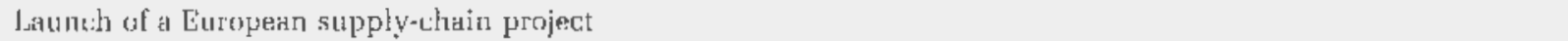 \\
\hline & First assussment of the implementation of POEMS anong ANVK tuur operators \\
\hline 21305 & l.aumb af a weh portal on sustainable vacations \\
\hline \multirow[t]{6}{*}{ Aflir 2005} & Publication al a brochure an CSR in the tourisun and travel industry (2006) \\
\hline & Launch of the Dutch Travel Foundation $(2007-10)$ \\
\hline & Laund uf the new AVVR sustainable business program [replacing ['OEMS, post-2008] \\
\hline & Laundu ul assessment tool of sustainability petfomanou of tourisin suppliors (post-2008) \\
\hline & $\begin{array}{l}\text { Inclusion of touristri in the Dutch Sustainable Trade lnitiative to promote sustanahle tourism in popular vacation } \\
\text { destinations (post-2009) }\end{array}$ \\
\hline & 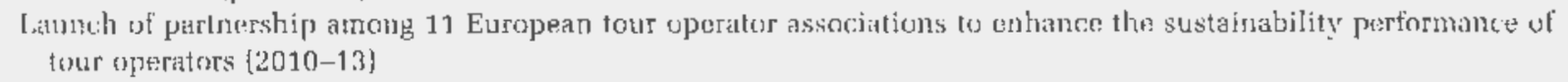 \\
\hline
\end{tabular}

alternative time windows to ensure that the findings were robust to these specifications.

To assess the evolving topalogies of the founder. theorizer, and merged networks in relation to fieldlevel change, we extracted several global network properties. These properties included size (number of actors and events). turnover (entry and exit of actors), and cohesion (number of network components and cliques) (Tablo 4). After visual irspection of the network graphs (Figure 1), wo formally assessed the "small-worldliness" of the networks" main component (i.e., the largest subset of mutually reachable nodes). transforming them into oneinode networks in which $X_{i i}=1$ when actor $i$ is connected to actor $j$ llyuugh at least one common evont affihiation, and $X_{i j}=0$ otherwise. We assessed the small-worldliness ( $S W$ ratio) of the annual networks (Table 4). ${ }^{5}$ The greater the SW ratio,

\footnotetext{
5 The formula used to calculate the SW ratio is [C $C_{\text {an ent }}$

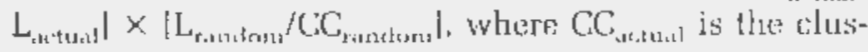


TABLE 4

Descriptive Statistics of Founder, Theorizer, and Merged Networks

\begin{tabular}{|c|c|c|c|c|c|c|c|c|c|c|c|c|c|}
\hline Variables" & Pre-1995 & 1995 & 1996 & 1997 & 1998 & 1999 & 2000 & 2001 & 2002 & 2003 & 2004 & 2005 & Total \\
\hline \multicolumn{14}{|l|}{ Fonnder Nitwork } \\
\hline Nt:w organizalions & 9 & 2 & 1 & 0 & 1 & 1 & 2 & $\mathrm{l}$ & 3 & 2 & 2 & \pm & 25 \\
\hline Now projects & $\mathrm{g}$ & 1 & 3 & 1 & a & 10 & 4 & G & 5 & a & 5 & 3 & 57 \\
\hline $\begin{array}{l}\text { C'unulative number of } \\
\text { fonnding ovents }\end{array}$ & 18 & 21 & 25 & 26 & 33 & 44 & 50 & 57 & 6.5 & 71 & 78 & 82 & 82 \\
\hline Naw founders & 13 & 2 & 2 & 1 & 5 & 11 & 6 & 6 & 12 & 5 & 2 & 3 & $\mathrm{sB}$ \\
\hline Fuuduter exits & 0 & 0 & 0 & 0 & 0 & 0 & 6 & 2 & 0 & 3 & 11 & 7 & 29 \\
\hline $\begin{array}{l}\text { Wain component size } \\
\text { (actors/urents) }\end{array}$ & & $3 / 7$ & $3 / 9$ & $3 / 9$ & $4 / 9$ & $11 / 15$ & $10 / 15$ & $13 / 13$ & $18 / 20$ & $24 / 31$ & $23 / 45$ & $22 / 48$ & \\
\hline Average density & & 4.67 & 5.33 & 5.33 & 4.50 & 4.18 & 3.40 & 3.85 & 4.00 & 4.83 & 4.52 & $5.0 \overline{5}$ & \\
\hline Average path lumgth & & 1.33 & 1.33 & 1.33 & 1.00 & 2.42 & 2.33 & 2.27 & 2.34 & $2.50)$ & 2.89 & 2.31 & \\
\hline SIV' ratio & & 0,00 & 0.00 & 0.00 & 0.82 & 1.40 & 1.83 & 2.46 & 3.57 & 3.53 & 3.20 & 3.13 & \\
\hline \multicolumn{14}{|l|}{ Therrzer Worwork } \\
\hline Naur publigations & 13 & 5 & 2 & b & 4 & 6 & 19 & 4 & 4 & 4 & 11 & 7 & 117 \\
\hline Nost kaynotes & 2 & 1 & 1 & 0 & 1 & 4 & 5 & 1 & 1 & 4 & 2 & 3 & 25 \\
\hline Now workshops & 0 & 1 & 1 & 0 & [] & 1 & 1 & 1 & 1 & 1 & 1 & 1 & 9 \\
\hline $\begin{array}{l}\text { Cumulativa mumbne of } \\
\text { thernictre urents }\end{array}$ & 45 & 52 & 56 & 64 & 69 & 80 & 105 & 111 & 117 & 125 & 140 & 151 & 151 \\
\hline New theorizors & 56 & 7 & 5 & 7 & 5 & 24 & 27 & 17 & 14 & 15 & 16 & 9 & 202 \\
\hline T'huerizes oxits & 0 & 0 & 0 & 0 & 0 & 24 & 5 & 4 & 9 & 1 & 17 & 27 & $B 7$ \\
\hline $\begin{array}{l}\text { Mrin component size } \\
\text { (atutors/ovents) }\end{array}$ & & $13 / 18$ & $\mathrm{j} 4 / 1 \mathrm{y}$ & $14 / 2\rfloor$ & $14 / 21$ & $41 / 41$ & $\mathrm{~A} 1 / 62$ & $79 / 7 \mathrm{G}$ & $81 / 77$ & 10)/8h & $99 / 90$ & $87 / 84$ & \\
\hline Awneage dersity & & 3.23 & 3.14 & 3.14 & 3.14 & 7.46 & 7.80 & 9.96 & 9.78 & 9.55 & 4.86 & $9.7 \mathrm{~g}$ & \\
\hline Mvorage path longh & & 2.24 & 2.33 & 2.33 & 2.33 & 2.49 & 2.55 & 2.535 & 2.60 & 2.63 & 2.54 & 2.53 & \\
\hline Sid ratio & & 3.54 & 3.97 & 3.97 & 3.97 & 3.59 & 5.28 & 5.74 & 5.46 & 7.24 & b. 85 & 5.84 & \\
\hline \multicolumn{14}{|l|}{ 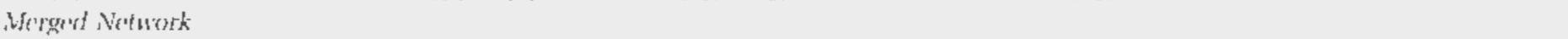 } \\
\hline Total actors & 53 & 72 & 78 & 85 & 94 & $7 \theta$ & 95 & 108 & 127 & 137 & 132 & 117 & 237 \\
\hline lotal urents & 63 & 73 & 81 & 901 & 102 & 101 & 133 & $1+4 i$ & 760 & 175 & 196 & 211 & 23.3 \\
\hline Number of riliquest & & 3 & 3 & 4 & 5 & 7 & 13 & 17 & -17 & 20 & 24 & 25 & 32 \\
\hline $\begin{array}{l}\text { Numbut of netwrork } \\
\text { conpoorknts" }\end{array}$ & & 7 & 8 & 8 & 7 & 4 & 4 & 3 & 3 & 2 & 2 & 2 & \\
\hline $\begin{array}{l}\text { Main componenl size } \\
\text { (actors/events) }\end{array}$ & & $14 / 2 \overline{3}$ & $\mathrm{I} .5 / 29$ & $15 / 31$ & $19 / 36$ & $51 / 70$ & $72 / 105$ & $92 / 127$ & $101 / 134$ & $120 / 150$ & $115 / 165$ & $106 / 157$ & \\
\hline $\begin{array}{l}\text { Percont artors in main } \\
\text { cumponent }\end{array}$ & & 19.44 & 19.23 & 18.29 & 20.21 & 65.38 & 75.79 & 65.19 & 79.53 & 87.59 & 87.12 & 90.60 & \\
\hline Aremgo donsity & & 3.14 & 3.07 & 3.07 & 3.16 & 6.86 & 7.31 & 8.59 & $9,0 . \overline{3}$ & B.97 & 4.46 & 9.09 & \\
\hline Averabt pall losigth & & 2.30 & 2.38 & 2.34 & 2.87 & 2.71 & 2.67 & 2.74 & 2.68 & 2.72 & 2.62 & 2.64 & \\
\hline Suv mio & & 4.02 & 4.46 & $4.4 k$ & 4.61 & 4.82 & 6.74 & 7.07 & 7.50 & 9.12 & 8.33 & 7,84 & \\
\hline
\end{tabular}

" "SW" is "smatl norld."

th Cliquas with a miniumbm size of two actors and two erents.

' Mintulum of firo nodes.

the more the network exhibits small-world properties (Davis, Yoo, Baker, 2003; Uzzi \& Spiro, 2005). $A$ higher SW ratio indicates that the network has substantially higher levels of local clustering than a

tering atefficient in the actual network, $L_{\text {it:ilum }}$ equuls the average shortest path between any two actors in the actual network, CGrind is the average clustering coefficient in the landoraized network, and $\mathrm{L}_{\text {rastem }}$ equals the average shortest path length in the randorn notwork (see Kogut and Walker [2001] and Uzzi and Spiro [2005] for details). comparable random network, while the average path length between its nodes is still similas to the random network (Baum, Shipilov, \& Rowley, 2003). All measures were calculated using LUCINET 6 (Borgatti, Everett, \& Frøeman, 2002).

Next, we identified cliques of actors in our network data set. Following Rowley et al. (2005), we used an $N$-clan procedure that considered only cliques in which members were at most two steps apart from all others, setting the minimum cilique size at two individuals and two events (cf. Borgatti \& Evorett, 1997). We found 32 unique cliques in the 
FIGURE 1

Merged Network of Movement Actors and Events, 1980-2005

(1A) 1985

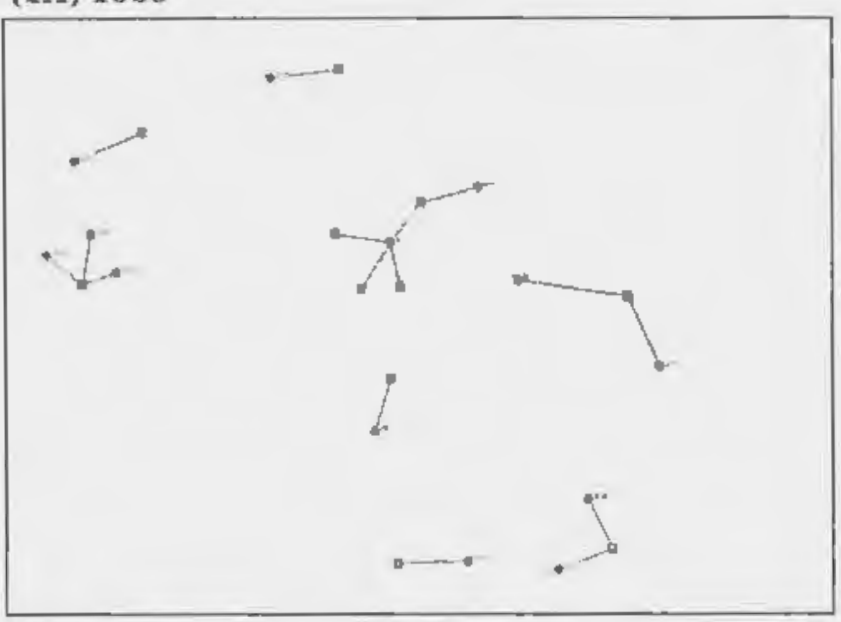

(1B) 1990

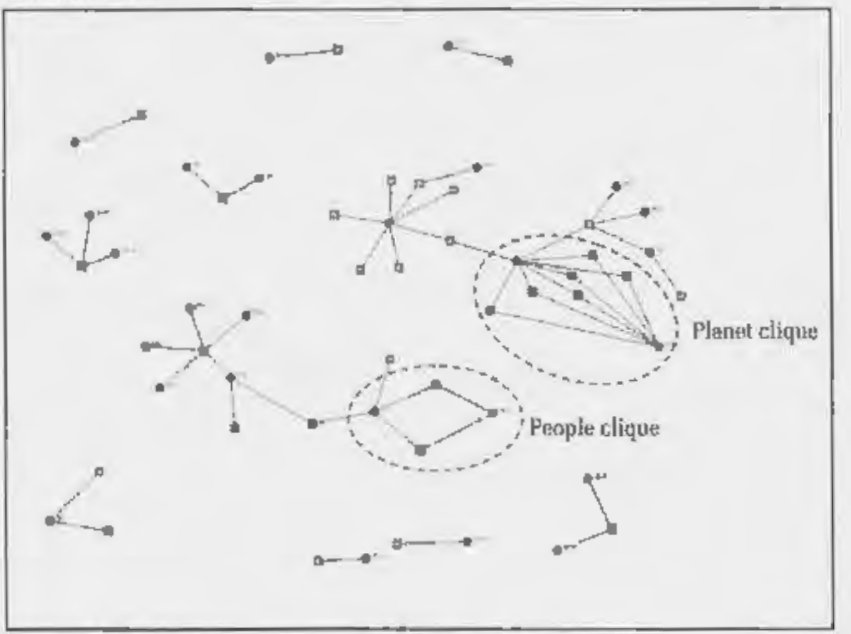

(1C) 1995

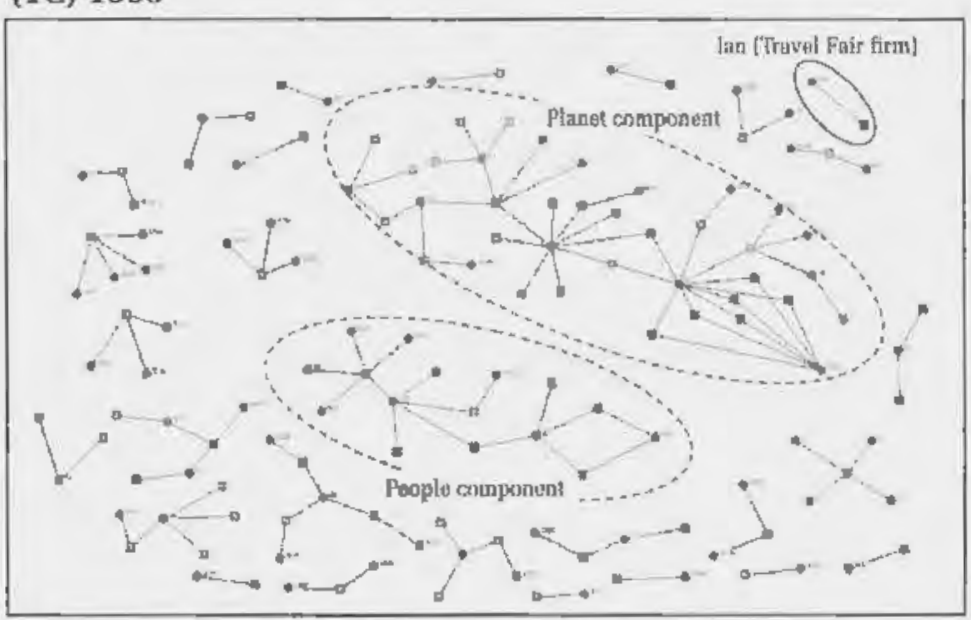

(1D) 2000

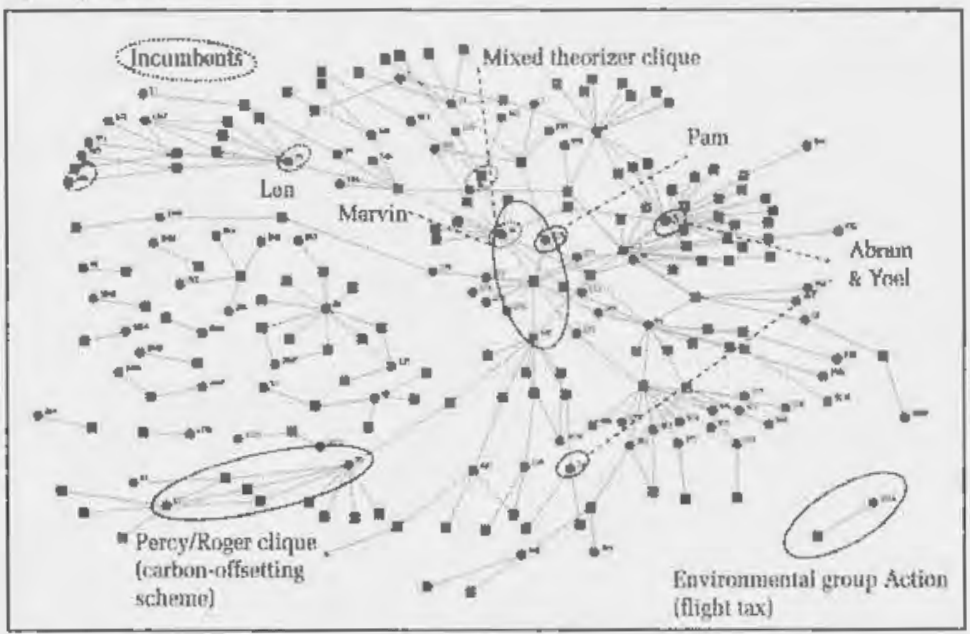

(1E) 2005

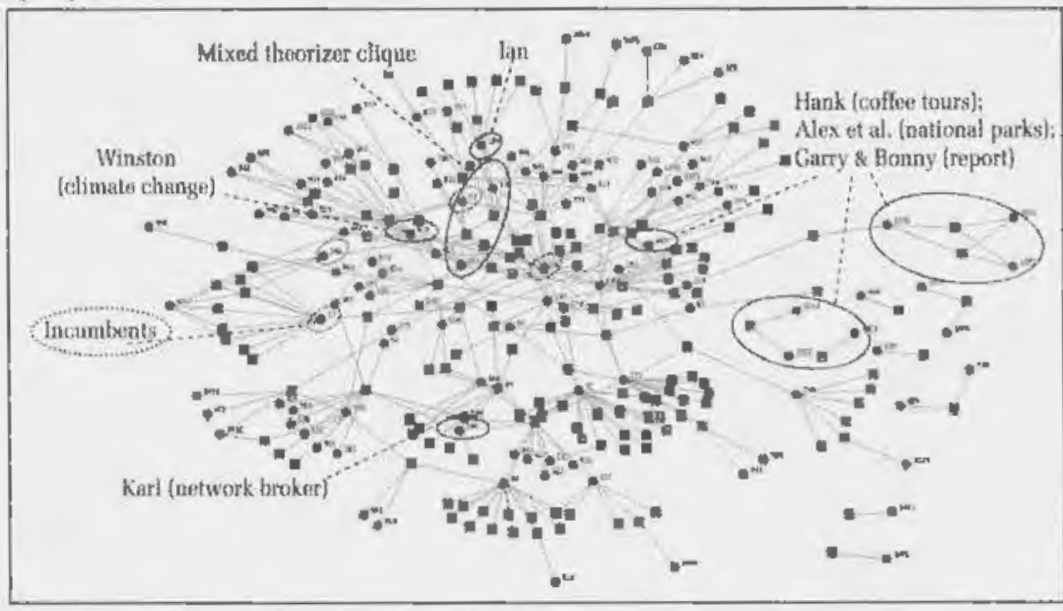

Nade key:

Circles = Movement members, inciuding activists and field incumbents

Dark squares $=$ Founding events

Gray squares $=$ Theorizing events 
merged network that produced "empirically traceable effects" (Rowley et al., 2005: 515) on the change process, in that the cliques' issues and practices had been included in ANVR's 2004 POEMS course book (Appendix B, availahle from the first author, provides examples).

Finally, we focused on the individual level. We recorded the annual frequencies with which actors performed founder and/or theorizer activities to assess the intensity of their engagement with the movement. We also identified brokers who bridged "structural holes" (Burt, 1992) by calculating betweennoss centrajity scores for all individuals in the annual founder, theorizer, and merged networks. Prior to calculation, we transformed each two-mude matrix into a bipartite graph (Faust, 1997) and then performed the calculations using UCINET 6 (Borgatti et al., 2002).

Parallel to the network analysis, we followed Berg (2004) in coding our interviews, focusing on instances of agency and their effects on the movement's and field's norms, practices, and interaction patterns. Four clear themes emerged. First, respondents used role lahels such as "rebel" to refer to individuals who consistently challenged the industry and "project addict" or "innovator" to describe their peers who consistentiy launched new projects and ventures, alerting us to distinct roles performed based on actors' activities. Second, sustainability was defined in terins of "People" and "Planet," suggosting that different cultural materials were produced in the movement. Third, respondents typified the collective as "cliquish" and as an "in crowd." which was supported by the first author's intensive fieldwork and our social network findings. Fourth, the POEMS tool was classified as a critical "innovation" and "breakthrough" in the change process. As such, the interplay of agency and the collective relational and cultural structures this agency produced became observahle,

In the final analytical stage, we revisited our materials to systematically examine this interplay over time. As recommended in process research (Langley, 1999), we refined our case chronology into two stages using our global network data (i.e., the SW

\footnotetext{
"People, planet, and profit are the three "Ps of sustainability" (Elkington, 1997). In the area of tourisn, "people" issues include indigenous people, human rights, fair wages, wealth distribution, cultural heritage, and childsex tourism. while "planet" issues include pollution, waste, water and encrgy use, biodiversity, and climate change.
}

ratio) to understand how agency in Stage 1 led to changes in the context that affected agency in Stage 2.

To examine individual agency, we drew on our social network indicators (i.e., degree of theorizing and/or founding and hetweenness centrality scores) to identify the core actors in the movement. We classified them into a 2 hy 2 matrix [i.e.. high-low engagement in theorizing versus founding), inciuding details on the years in which the actors were active and occupied critical brokerage positions in the movement. Based on this overview, we sorted all interview and text material hy key actor. Wo highlighted texl fragments rogarding these actors" contributions to the change process, specifically looking for any role laheling. Moving back and forth between these text exiracts, social network indicators, and the pertinent literature, we identified six roles (issue-entrepreneurs, clarifiers, innovaturs, sponsors, network brokers, and cultural brokers $^{7}$ ) and then reviewed our materials to identify who performed which role over time.

Ta examine contextual changes in the movement at the meso level of action, we systematically examined the activities of the 32 cliques and coded each in terms of its cultural focus (People, Planet, or "mixed"). We found that the cliques" natures differed for each stage. Whereas cliques that formed around particular issues to produce cultural materials developed over both stages, only in the second stage did cliques emerge that were hased on joint theorizing activities that blended cultural ideas.

To understand the recursive relationship hetween agency and the evolving macrolcvel context, we sought textual evidence of role interdependencies and contextual factors that affected them. For instance, we examined the interviews of clique members to identify the antecodents, motives, and outcomes of collaborations and revisited our other materials to seek instances of actors huilding upon or contributing to the rreative work of others. By relating the roles to the evolving cuitural and rela-

\footnotetext{
${ }^{7}$ Issue-entrepreneurs engage in both theorizing and founding to critique extant practicos and those using them, and to experjument with alternatives. Clarjfiers describe the need for change and outline potential solutions through theorizing. Innovators put these ideas intu practice by founding altomative organizational forms, products, and practices. Sponsors provide resuurces such as grants and venues for such creative work. Network brokers establish connections across different parties, while cultural brokers merge various cultural elements into a dominant template.
} 
tional strutures in the muvement over time and curroburating insights from our textual analysis of role intertependoncies, we were able to move to a hipher level of abstraction in our role labeling. We identified a category of instigators, or at:tors who originizted new jdeas ur practices (i.c., issue-entreprenents, rlarifiers, inmovators, and sponsors]. Those instigaturs sot the stage for brokers, the actors who combected people and ideas across distinct cliqurs and discourses \{i,e., network and cultural brokers). 'lo ultimately develop a chronology of the interplay of individual agency and coltural and relational strustures acruss levels of analysis (i.o., clique and global network), wo compared ovidence of movement internal dynamics to evidence of institutional albange in the wuthome tour operations field, as shown in Table 5.

These five analytical stages reflest the overalt trejectory of vur explorative rescurch. It should be noted. liowover, that the research process resembled episudes of "intense discussions" and "trialandmerror "lawings" to achieve "what, in the cnd, felt right and true to the data" (Smith, 2002: 395). To ensure the validity and reliability of the qualitative analysis, we logged nur data-reduction steps. triangulated data and methods, and used memher checking at scveral points in the analysis (GTeswo)l \& Miller, 2000: (ibbert. Ruigrok, \& Wirki, 2008). To protect respondents' identities, we use pseudonyms and quote then as "RES-continuous letter."

\section{FINDINGS}

We detail the chronology of how indeptendent activists gained a foothold in the Dutch outhound tour operations field. As illustrated in Table 5, this transformation unfolded in two main stages, distributed instigation and coordinated "costructurafion." featuring differmt degrees of cultural and rolational structuration, incumbent involvement. and impact on the field's norms and prectices. Distributed instigution refers to the origination of now ideas and practices by agents acting independently, and coordinaled costructuration describes the cor ordiuated efforts of members of a collective to structure llieir social arena with shared meanings and practions.

\section{Stage 1: Distributed Instigation (1980-97)}

In the first stage. multiple, isolated agonts drew upon the shlubal mactrocultural discourse on sistainable fourism that emerged in the 1970 s and 1980s and hecane involved in adrancing sustainable tuurism in Dutch outbound tour operations. Those instigators also connocted with one muther to furm rliques (as shown in Figures $1 \mathrm{~A}-\mathrm{C}$ ). Over 85 different acturs engaged in at loast one of the 20 founding ovents and 64 theorizing events yocorded during this first stage. as shown in Table 4. Because agency is inextricably linked tu structuration, we describe both together.

Agency and cultural structuration. Sev'eral activists created a cultural discourse in the Dutch context to highlight tho need for sustainahle tourism. l'or example, having observed the negative impacts of mass wintor-sports tourism, Abran and Bart (actors 92 and $10(11$ in Figures $1 \Lambda$ and 13 ) founded an envirommenlial study group on the $\Lambda$ ps in 1982. Similarly, Geoff and Kamal (actors 272 and 38) joined a study group that educated volunterss working in oxutic: locations. In 1986, they foundet the Tourism and Thire World Eoundation and organized a conference on this theme. Criticizing the consequences of mass tourism, these activists used expressions such as the "wotnded $\Lambda l_{p s}$," "bleeding nountainss. "and "[10urisn as] the new Western colonialism." Their activities generated substantial media coverage.

Other instigators lewitinized the activists claims. Limploysd by a prominent tourisiu school and, therufore, a member of the iucumbent fintd. Eliot (actor 59) published a textbook on sustainablo tourism in 1989 that promoted the issue as an inrlustry concerm. Indered, archives show thut ANVR noted his arguments and croated its informal Executive Committee on Sustianalyle Itourism in rosponse to the energing robate that same vear. Tho Committee drattod an environmental Codc of Conduct that was accepted hy the organization's members in 1992. Other instigators added to the antivists' discourse in this stage, including Roy (actor 8 ). who commented on the ritationship betwen tourism and nature conservations: scientist Hakan (actor 88 in Figure 1C). who published on tourisn in developing countries: and Tom, Trank. WVim, anrl Ann (actors 1040-43). who published a popular textbook on sustainalule lourism in 1993.

Other acturs began to found organizations. introducing new practices and orgmizutional forms the ficld. For instance. lan (actor 289 in Figure 16) launched a new tourism venture in 1993 that promoted "Fair tomrism" in develuping countries. drawing on the global discourse that had bon brought to his attention by Geoff. This firm was considered the prototype organization that "inte- 
TABLE 5

The Evolution of the Movement and Field on Sustainable Tourism, 1980-2005

\begin{tabular}{|c|c|c|c|}
\hline Movement/Field & \multicolumn{2}{|c|}{$\begin{array}{l}\text { Stage 1: Distributed Instigation, } \\
\qquad 1980-97\end{array}$} & $\begin{array}{l}\text { Stage 2: Coordinated Costructuration, } \\
\qquad 1998-2005\end{array}$ \\
\hline Agency & Distributed activity by actors in inst & gating roles & $\begin{array}{l}\text { Coordinated activity brought about by cultural and network brokers and } \\
\text { effective mobilizing struciures (i.e., IDUT platform, Groeneveld and other } \\
\text { conferences) }\end{array}$ \\
\hline Culture & Heterogeneous cultural materials for & ned around particular issues & $\begin{array}{l}\text { Dominant template (i.e., POEMS) that nnifies and organizes heterogeneous } \\
\text { cultural materials }\end{array}$ \\
\hline \multirow[t]{2}{*}{ Network } & $\begin{array}{lll}0 & 0 & 0 \\
0 & 0 \\
0 & 0 \\
0 & 0 & 0 \\
0 & t o\end{array}$ & 0 & \\
\hline & Independent, individual actions & $\rightarrow$ Cliques & Cliques \& components \\
\hline $\begin{array}{l}\text { Movement- } \\
\text { Field } \\
\text { connectivity }\end{array}$ & $\begin{array}{l}\text { Ad hoc involvement by individual } \\
\text { tour operators in movement } \\
\text { projects }\end{array}$ & $\begin{array}{l}\text { Institutionalized involvement by lead } \\
\text { incnmbents in IDUT platform }\end{array}$ & $\begin{array}{ll}\begin{array}{l}\text { Strategic involvement by (lead) } \\
\text { incunbents in IDUT platform, }\end{array} & \begin{array}{c}\text { Proactive involvement of (lead) } \\
\text { incumbents, co-initiating projects } \\
\text { conferences, newly launched } \\
\text { projects, and organizations }\end{array} \\
\text { rather than only participating in } \\
\text { movement projects }\end{array}$ \\
\hline $\begin{array}{l}\text { Field norms and } \\
\text { practices }\end{array}$ & $\begin{array}{l}\text { Outbound tour operators are } \\
\text { merely vacation sellers. } \\
\text { Responsibility for sustainable } \\
\text { tourism lies with vacation } \\
\text { destinations. }\end{array}$ & $\begin{array}{l}\text { Outbound tour operators are advisers } \\
\text { in sustainable tourism. As it is a } \\
\text { collective responsibility to safeguard } \\
\text { the future of the tonrism industry, } \\
\text { measures such as Codes of Conduct } \\
\text { and inclusion of environmental } \\
\text { information in the industry database } \\
\text { are adopted. }\end{array}$ & $\begin{array}{l}\text { Sustainable tourism is the individual responsibility of each tour operator, } \\
\text { evidenced by the obligatory POEMS scheme. Outbound tour operators, } \\
\text { being socially respoosible, should implement sustainable tourism } \\
\text { measures. }\end{array}$ \\
\hline
\end{tabular}


grated sustainahle tourisin from $\mathrm{A}$ to $\mathrm{Z}$ in its operations" (RES-N). The firm was watched closely by incumbent adventure tour operators who felt threatened by this venturc. Others focused on environmental sustainability: Perry (actor 62) launched an "ecolabel" for outdoor firms in 1992 and the Foundation for Tourism and Sea Turtles in 1993, and Woody and Yoel (actors 147 and 24) founded a nonprofit organization in 1992 that offered sustainable farm vacations in Eastern Europe through Green Tours, a niche-player at the time that has subsequently grown into a respected tour operator. Yoel explicitly stated that his strategy was nol tu criticizo the industry but to offer alternatives and, thereby, alter the supply chain. In sum, various actors instigated practices, organizationa] forms, and discourse that could be claborated upon by others, helping an understanding of sustainahle tourism to cmerge.

Agency and network structuration. While instigators often hegan their work alone, uver time, networks formed among actors who focused on the different definitions of sustainability found in the macrocultural discourse, as shown in Figure 1B. Abram and Bart, for instance, studied at the same university and, as mountaineers, observed firsthand the environmental impacts of tourisin in the Alps. They later formed a Planet clique. Similarly, traveling to developing countries with Tess inspired Kamal to arganize workshops for those interested in tourism in devoloping countries. Genff was one of the students. In the late 1980s. Tess and Kamal formed a People clique that published educational materials on responsible tuurism with respect to local communities.

Cliques also emerged as activists jorkeyed for like-minded partners who could provide the necessary resources to advance their projects (Baum et al.. 2003). For instance, Ahram and Bart asked Roy, who worked for the Royal Netherlands Tourist Society, to help spread their message "more widely" (RLS- $\mathrm{A}_{2}$ ) to the Society's millions of members. Roy and Abram also lohbied to get the Tourist Society and various mountaineering and ski associations to collaborate for sustainahle winter-sports vacations. A joint platform was latinched in 1991 .

Consequently, during Stage 1. two major disconnected sucial circles emerged with their separate discourses and practices: "People" versus "Planet." This fragmentatinn was also discernihle in the movement's network structure in 1997, which comprised scveral unconnected components (see Tahle 4, kigure 1C). As one respondont explained,
I did not do a lot with nature issues: that wis a totally different direction. Wo were working on sociocultural issues, like respectful tourist behnvior and so on; as far as we werc concerned, it was not about the environmont. (RES-K, omphasis added)

In comparison to the People clique, the Planet clique received more funding and was more influential, better organized, and "botter represented at the governmental Level" (RES-HH). For example, the Advisory Council for Nature Policy, a highly authoritative government body, produced a 1994 report proposing a flight tax. The propusal "came as a shock" and was experienced as "a frontal attack on the tourisn industry" (RES-J $)_{1}$ ). In response to the report, the Ministry of Nature Conservation or" ganized the first national conference on sustainable tourism in 1995 and launchod the multistakehnlder IDUT platform in 1996. Although these structures were ad hoc at the time, each provided a way lo build and strengthen network connoctions among movement members (initially primarily on the Planet side) and between the movement and powerful incumbents. Wary of government interference in air travel, ANVR assumed the role of chair of the stakeholder platform "to take the lead and keep the initiative" (RES-D). The IDUT platform organized a second conference in 1946. to which the Planet clique contributed. Over time. the movement thus became increasingly structured and connected to the incumbent field.

Agency, culture, and network interoctions. As seen from the description of agency. culture. and netwnrk structures abovo, the three interacted quite meaningfully. Instigators created cultura elements, which helped to form network structures that, in turn, advanced the development of more cultural elements and created space for more agency. For instance, being familiar with the Alps study gronp's publications, Roy referred to the Alps in his thoorizing to demonstrate how Dutch tourists harm the environment. Once the Planet clique was formed, the Alps study group, in turn. took inspiration from Roy's Tourist Society's water-sports campaign whon developing its winter-sports canpaigns. The Advisory Cotrncil's 1994 report also drew on the work of instigators (e.g. . Abram, Peroy, and Hakan) to critique outbound tourism and demand action from the government and industry. Collective identity also began to enuerge within cliques; the People clique was more radical because of its links to the fair-trade-in-tourism global move- 
ments, whereas the Planet clique was more reformist.

As the sustainable tourism discourse became more visihle and elaborated, facilitated by local clique networks, agency was also enabled. New instigators entered the movement and were able to draw on a substantial legitimating discourse for their initiatives. Even in the incumbent field, agency was enabled, as shown by the launch of ANVR's Committee on Sustainable Tourism and its Code of Conduct. In sum, instigators began to collahorate, as is discernible in the clique formation, The cliques created fertile ground for the sustainahle tourisn movement as they enabied activists to increase the visihility of their issues, share and create knowledge, and coordinate their activities. Because the People and Planet cliques remained disconnected, howcver, the movement was still too fragmented to effectively forge field change.

\section{Stage 2: Coordinated Costructuration (1998-2005)}

In Stage 2, lead jncumbents and others acted as cultural and network brokers, starting a process of coordinated costructuration between movement and field. Cultural brokers nerged various cultural elements within the movement into a dominant femplate, which we define as a structured set of concepts and practices and their cross-linkages that are commonly accepted by a collective, such that actors future behaviors and interpretations are guided by this template. Network brokers established social ties among dilferent cliques, thereby linking them into a small-world network (Watss, 1999). Mobilizing structures such as the IDUT plat= form, conferences, and industry trainings helped to further shared meanings and estahlish networks. This confluence of cultural and relational structiration resulted in a "tipping point" in the evolution of the movement and the field, at which the pace of innovation accelerated, but its radicalness becane diluted, creating the conditions for ongoing, incremental field change. We next detail these dynamics.

Agency and cultural structuration. By 1998, instigators had created a wide variety of alternatives for incumbent tour operators to address their currently unsustainable practices. Examples included ecolabels for clcan heaches and outdoor firms, accommodation checklists, an airship campaign, and educational materials. The initiatives were sometimes too unrealistic and radical to implement ( $\mathrm{RES}-\mathrm{O}_{2}$ ), making the issue complex and confusing for tour apcrators. To help firms systematically embed diverse practices in their operations, ANVR (led by Len, actor 77 in Figure 1D), assisted by an environmental managemont consultant, took on a cultural broker role by designing a POEMS policy tool for tour operators that integrated sustainable tourism issues.

By developing this tool, ANVR aimed to influonce the pace and direction of the change process. It did not want to "remain on the sideline" and "continue to be overthrown by criticism" (RES-O $\left.{ }_{2}\right)$ but, rather, to "be ready in full armor" (RES-B ${ }_{1}$ ), ir case pressures increased. Sinilarly, adopting the movement's language, ANVR published a public brochure in early 1998, touting sustainable tourism as "a lasting goal" rather than "a fad that fades out" (ANVR, 1998: 3). The brochure further listed the movement members under the heading "They play the game with us" (ANVR, 1998: 15) and highlighted the points of departure for "an effective shared policy" (ANVR, 1998: 3), expressing a cooperative attitude while also setting the terms for such collaboration.

The POEMS scheme provided checklists of People and Planet issues and best practices for deaîng with them, which had been pilot tested by firms and assessed as feasible by ANVR's Executive Committee on Sustainable Tourism. Importantly, the practices in POEMS were framed in the typical supply-chain language used by tour operators rather than in the activists' discourse of tourism impacts. A POEMS training course for tour operators was also developed, helping to promote POEMS and emhed it in the field. Experiences with POEMS were discussed with toli operators via ANVR's annual meetings and publications as well as with the movenent via conference presentations and the JDUT platform (see incumhonts in Figures $1 \mathrm{D}$ and 1 E). Table 6 illustrates how POEMS embedded the People and Planet issues into the tour operator's supply-chain language. Respondents were unanimous about the importance of POEMS for the change process; it was a "breakthrough" (RES-C. $\mathrm{C}_{2}$ ), "fairly unique" (RES-R $\mathrm{R}_{1}$, and "an admirable development" (RES-L).

Agency and network structuration. Figuros 1C-E show how the discrete network components that had formed during Stage 1 became connected. Notably, in approximately 1999, the movement's relational fabric underwent a significant transformation. Table 4 reveals that the network increasingly exhibited small-world characteristics, as re- 
TABLE 6

POEMS as Dominant Template for People and Planet Practicesis

\begin{tabular}{|c|c|c|}
\hline Product Development Stage & Illustration of Practices Meutinned & Issue \\
\hline Infornation & $\begin{array}{l}\text { Pmvide inforutation on the: Blue Flag label } \\
\text { inforn tourists about child-sex taursin }\end{array}$ & $\begin{array}{l}\text { Plinet } \\
\text { finl? }\end{array}$ \\
\hline Transportation & Apply ICCL guidelines tor cruiso vacations & Haru! \\
\hline Acuommodation & $\begin{array}{l}\text { Lise purchasing checklists with onwironnuntal critoria } \\
\text { lnvest in local community projects }\end{array}$ & 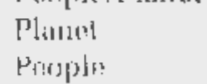 \\
\hline Leisure & $\begin{array}{l}\text { Promote ECPAT's campaign ageinst child-sux tomivisn } \\
\text { Collaborate with certifind diving sobools }\end{array}$ & 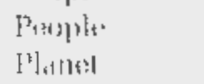 \\
\hline Internal murilonmmnta! matitgement & $\begin{array}{l}\text { Kecycle waste } \\
\text { Reduce energy and water use }\end{array}$ & $\begin{array}{l}\text { Plimet } \\
\text { Platuet }\end{array}$ \\
\hline
\end{tabular}

"FTum the ANVR (2003) Sumbury POEMS Action l'lar.

flected by the sharp increase in tho SW rativ after 1990. This shango stiggests that the movement's members, although mostly embedded in subgroups, were now only a few links removed from each other. The small-world emergence was supported by our interviews. in which respondents referred to "a cozy club" ( $\left.R E S-M, O_{1}\right)$ and "an inr.rowd of penple who all know each other" (RES-E). Yoel's observation implicitly recognizes the movement's evolution toward increased integration:

We started and at a certain point you meet others. . . You hoar about the othors. but there is no connection yel. Aftcr a while, the initiatives converge muru and more, you meet each other and then the whole thing starts integrating. Perhaps you become a compotitor or you start to cuordinate issues. you gat coalitions and groups that collaborate and groups that got along less well with one another.

The IDUT' platform and conferences, as well as the actors' agency, played a pivotal role in the transformation of the movement into a small-world network, connecting People, Planet and field incumbents. The IDUT platform. launched in 1996. institutionalized the collaboration between activists and incumbonts after "checking each other out" (RES-L) and searching for a mission, membership criteria. and "points of departure" (RFS-M). Although the IDUT" platform initially had a pro-Planet bias. by late 1997, its membership also included People advocates, which helped tho platform to oversee developments in both camps. Conferences also facilitated network and cultural in tegration, as shown by the emergence of cliques based on joint theorizing activities at conferences, where People and Planet proponents shared ideas (see Figures $1 \mathrm{D}$ and 1E). The IDUT'T platform's annual Groeneveld Conference was particularly rolevant, heing "an im- portant ritual" and "signboard of the movement" (RES-C ${ }_{2}$ ).

In addition to the IDUT platfum and couslerences, several network brokers created clique-spanning ties. Рan (actor 129 in Figure 1D), who worked for a governmental body in intirnational cooperation that was already sponsoring sexeral movement initiatives, urganized a public: desute in 1999 to connect the Penple and Plinet groups and movement and field mombers. The confertunce? proceedings state that

The debate on sustainable tourism in llu: Nelherlands is characterized by o missing link. Sustainalye tourism is either dnfined in lerms of hature consersvation. ecology and the errvirmment, br stwh surial issues as child sex tourism, the hibur contilions of tourism employes, and mltmin sxchange. Y*t, we would like to see that a buad definition is appliut. .. Sustainable develupmont has sorial, eromomic, cultural and ecological dimtrsions. Whou dontoping tools. policies and oduchtural c:ampaigns. it is important to highlight all those dimensiugls. V van th? Pol, 1999: 2-3. emphasis added)

Movement member Marvin lactor 16 in ligure 1d) also served as a notwork broker when hired as environmental manager for the elite tour operator Travel Abroad in late 1998, and nominated as professor in sustainable tourism at a prominent tourism school in 1999. Travel Abroad ained to claim green leadership in the industry as a "slrategic move," as the inovement was no longer "a small group of fanatics" (IRES-I,L). Murvin used his pusition to connest the People and Planet cliques and, in turn, connect them to the field. Although Travel Abroad's moves clearly intluenced its actions. ANVR did not follow its elite member, instead pursuing its own agenda. An ANVR representative 
stated that "The change did in any case not come from within the industry; that has also been the major problem, right, to get the support of the industry" (RES-B $)_{1}$.

Agency, culture, and network interactions. We suggest that the brokers and the cultural and relational structuration they facilitated were interdependent. Cultural hrokers provided a motive and/or conceptual justification for network brokers to link with activists and incumbents and viceversa, Put differently, POEMS would have remained a paper tiger if Iinks had not been formed between the activists supporting the People and Planet solutions and between movement and field members to jointly work out the details of POEMS. Similarly, connecting the People and Planet cliques and the field would have been difficult without a template to guide these interactions. This confluence of cultural and relational structuration generated a tipping point in the evolution of the movement and the field. The smali-world network enabled activists to efficiently share knowledge about the need to innovate in order to implement POEMS, while the POEMS template allowed the field incumhents to convey information regarding which innovations would be considered feasible. Activists' knowledge and prompting accelerated innovative activity, while the feasibility requirements diluted the radicalness of innovations to fit the dominant template and, as a result, increase industry acceptance. As such, a process of coordinated costructuration between activists and incumbents occurred in Stage 2, prefacing the entry of the sustainable tourism issue into the membership and meaning system of the field. We noxt describe the increased speed but diluted radicalness of innovation in sustainablo tourism.

Acceleration of innovation. Small worlds enhance knowledge flow among network members, accelerating learning, coordination, and adaptation (Baum et al., 2003). As such. the emergence of a small-world network explains the sudden surge of theorizing and founding events in the late 1990s. For instance, Yoel learned about Abram's activities through his network, but the two "really got together" and "gear[ed] [their] activities to one another" in the early 2000 s (actors 24 and 92 in Figure 1D). Moreover, the introduction of the POEMS template increased the attractiveness of the small world for newcomers. As a condition of ANVR membership. POEMS created entrepreneurial op* portunities by creating demand for sustainability among tour operators. At the same time, POEMS reduced uncertainty for both instigators and tour operators. as it defined a rubric for sustainable tourism. Hank was a new entrant (actor 389 in Figure 1E) who Jearned about the commercial failure of four operator Travel Fair. Rather than developing vacation packages that were entirely sustainable. he offered "bite-sized chunks of sustainability" to tour operators. In 2004, for instance. he codeveloped coffee-farm tours in Tanzania that could he easily included in standard itineraries. Other new instigators included Alex. Chuck, and Peter, who developed vacations to national parks in 2002 (actnrs 1015, 1065, and 1072); Garry and Bonny, who authored a report on sustainahility in vacation transportation in 2002 (actors 1052 and 1054); and Winston, who entered in 2002 and raised the issue of climate change (actor 828). Now entrants also took on broker roles. For instance, Karl (actor 549) brokered between People and Planot proponents hy organizing a 2001 conference. By instigating and brokering, new entrants kept the small world alive and contributed to the collective social construction of POEMS.

Similarly, the short path length of small wurlds permitted activists to build upon the experiences and knowledge imbued in the netwurk and to adjust their initiatives to the POEMS model. Following the failure of his firm Travel Fair, for instance, lan launched a new carbon-offsetting organization in 2003 (actor 289 in Figure 1E). In so doing, he built on the ground covered by the Roger/Percy clique [see Figure 1d], which had developed a carhon-offsetting scheme as early as 1999 but found it difficult to glean industry support. lan explained: "The story of [their organization] was too complex. They were telling tour operators how bad flight vacations were, hut at the same time they needed to sell their certificates to them. so this was not going to work. . . ." Subsequently, he promoted his scheme as a legitimate solution to qualify for a POEMS certificate and eased adoption of the scheme via a web application.

In sum, the small-world network structure supported a new wave of mobilization and allowed for cross-fertilization between movement and industry. While the cliques continued to produce local knowledge, ideas, and practices with POEMS as a rallying point, connectivity among cliques helped speed up the circulation of knowledge, thereby caordinating these activities. With learl incumbents embedded in the small-world network, activists could access insider knowledge about the industry, as well as insider channels of communication and 
ristribution, to promote their creative offerings. Concurrentiy, fiteld incumbents gained access to the innovations in the movement in order to put the ubligatory POFMS template into practice. More inportantly, incorcased social interactions and the shared rOEMS language spurrod anlaboration between activists and field incumbents. For instance, a new sirpply-chain project to develop and promote sustainabls diving and beach tourism within the Netherlands Antilles was launchod in 1999, running until 2002. This project was "truly a joint project" in which "overybody participated" (RESL), including Dutch tour operators offering vacations to these islands. nature conservation organizations, educationd institutes, ANVR, diving schools. lootuks, and an airline company. And yot. despite the renewol mergy and activity, the changes were less radical than anticipated. Ou findings suggest that the same mechanisms that enabled the movement to gain momentum and increase acresss to the establishod field [i.o. the rominant template and the small-world network] also led to the dilution of the radicalness of its innowations.

Dilution of innovative radicalness. The small world quickly spreat the word on incumbent $i_{n-}$ volvement. "This morgized the movement greatly. becanst exisling movement members and new ontrants believed that change was within reach. However, the snall worh also circulated information on the conditions for endorsement of change by the industry, which was roinforced by POEMS, Our interviews suggest that frasibility was the naju criterion for industry ondorsenent:

Every mensure should he leasible. Thus. we the industryl approwh issues from an economic perspective: is it commertially desirable and is it commercially f'Hisiblo: That has always been the dominats princiglte of our work. (RLS-O)

l'hero was a rounstint ualling [by the industry] . . renumbilyer. dum't propose measures that are not commercially fatsiblo, heronso otherwisc wo do not participatt, there! is un consumer demand, so don't move tou fast. (RLS-A.)

The inklustrys focus on feasibility should be viewed in the context of a weak consumer demand for the sustainability of vacations and the waning of government interest in the issue that began in the late 1990s, although the debate over вir travel-und the flight tax-munained a latent threat.

Subsequmently, activists began to dovelop pracicos that were less radical: that is. they poserl fewre! constraints on the industry's daify business. Must extremely. a quota on the number of flight vacations allowed per person was rejected in favor of simply informing consumers about carbun offsetting. Thus, the movemonl's ultimate goal of developing fully sustainable tour oporating husinessts proved to be unrealistic. and activists adapted to what was foasible: "making the standard vacation packages |step-by-stepl moro sustainable" (RES-CG').

This dilution of the radicalness of innovation was further strongthened by the entranco of new, more pragmatic activists into the small worid. As one respondent put it.

In sustainable turism, there are pioneers who start things up, but at a certais moment their time is owor. because the dwareness has been tireated ind a new generation thon takus over. . . And thore is a new generation now, smch as Yuel, Buck, Hauk. Pablu. and Mary, the implementation people. (RES-C emphasis added)

Concurrently, the strong sense of belonging among the acturs who comprised the small world limited the willinganss and ability of attivists to push for radical innovations. Field work reveatul that activists and incumbents wonld greet each other warmly and combine work visits with soxial activities [Field motes. 2/11/06). Our metwork thata showed that ralical voices in the movement remained or becane periphoral. For instance, the onvironmental group Artion (actor 1066 in Figure 11) remained isolated, bejng "too leftist. too small a group. ton critical a story" (RL'S-A, Siritarly, whereas "radical" Cooff became a central player in the international finir-trade-in-tourisn movements. his position in the Dulch movement altered. He? remained central to the theorizer network, hut ht: became marginal to llye founder notwork, "becaluse new [less dingerous] people [tookl aver" and received funding (RF.S-N). This is not to say that such activists' ideas disuppeared from the agendr, but achioving support for their ideas required another sort of activist-"suit-and-tio pcople" (RES-GG)and practicess in a diluted form.

In turn, the dilution of the rtedicalnoss of innovetion helped ANVR to overcome its momburs' resistance to the POEMS sclieme. In 2000, members had agreed to make the scheme an obligatory nombership criterion by 2003. However, the relatively open small-world network structure and the nowe:ment's acceptanca of POLMS had made the change process harely visible to tour operators who dirl not directly interact with artivists. despite ANVR's and 
frontrunners' intensive promotions of the POEMS project. As a result, when ANVR urged its members to adopt POEMS in 2002 and 2003, most of them considered the scheme to be a top-down imposition and thus opposed it. Sustained social interactions with movement members, however, had turned ANVR into a strong believer in the need for change. After making several adjustments, changing its promotional strategy and postponing the deadline, in 2005, ANVR was able to exert semicoercive pressure on its members to implement the scheme.

In sum, the confluence of the POEMS dominant template and the small-world network strengthened the collaborative ties between activists and incumbents and facilitated their adaptation to one another. While activists adapted their "sustainability-above-all-else" logic to the field's language, practices, and priorities, incumbents revised their industry logic and practices to include sustainability. As such, the conditions for ongoing, incremental field change had been met: movement and field memhers increased their interactions within the IDUT platform, at Groeneveld Conferences and in project and industry neetings; shared a common meaning system evident in the collectively constructed POEMS as the dominant template; and recognized their mutual involvement in an institu- tional project to increase the sustainability of tourism through the gradual adaptation of tour operators' daily operations, supply chains, and vacation destinations (DiMaggio \& Powell, 1983; Scott, 2001).

\section{A PROCESS MODEL OF ACTIVIST-INSTIGATED FIELD CHANGE}

Drawing on our case study, we present a process model of activist-instigated field change in Figure 2. Central to our model is that movements vary in their levels of cultural and relational structuration over time, which affects their mohilizing capacities for impacting the organizational field under challenge. The model depicts how movements with moderate levels of structuration are able to prompt reflexive agency in field incumbents but also run the risk of cooptation. However, when multiple actors engage in cultural and relational brokerage between the movement and the field, members of both groups begin to shape themselves to the meaning system and social structure they cocreate, and cooptation becomes mutual. This confluence of cultural and relational structuration generates a tipping point in the evolution of the movement and the field, at which the pace of innovation accelerates, hut its radicalness is diluted, thereby cre-

\section{FIGURE 2}

Interplay of Agency, Culture, and Networks in Field Evolution

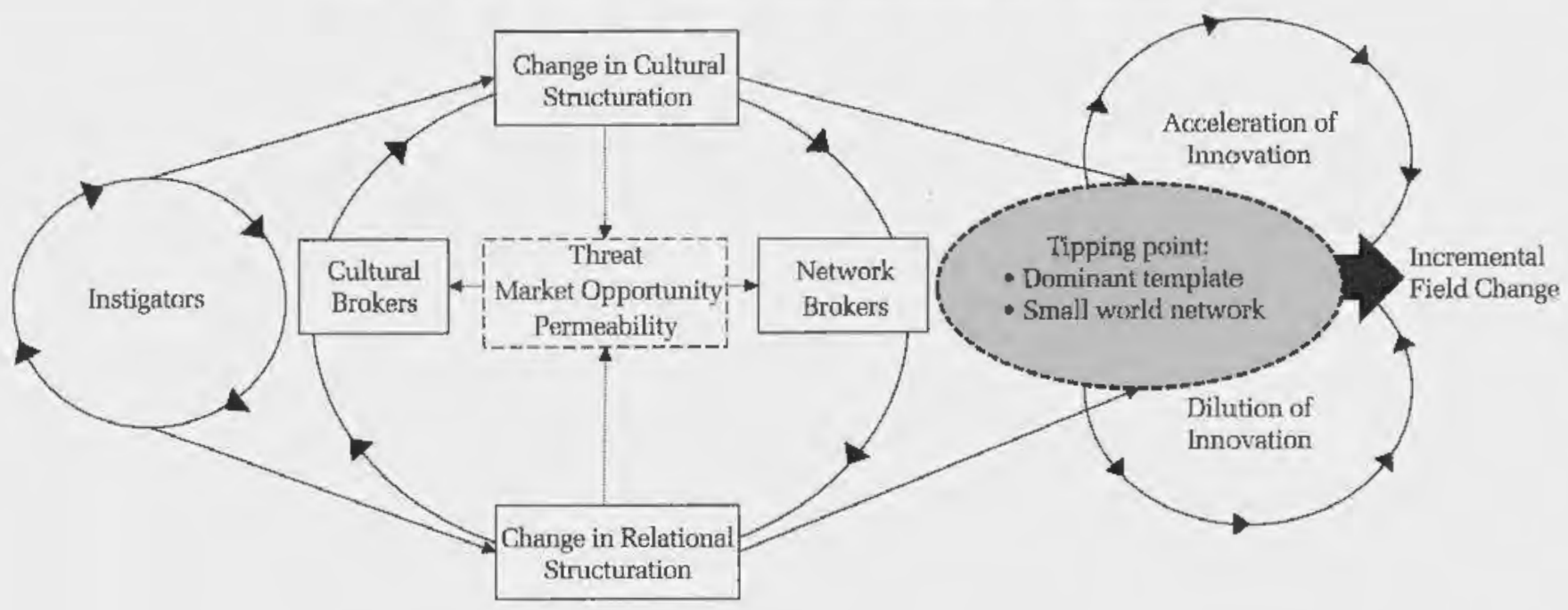

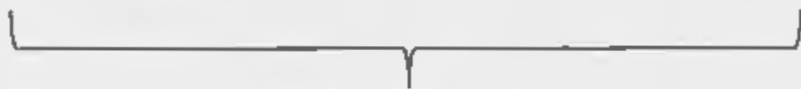

Distributed Instigation
Coordinated Costructuration 
ating the conditions for ongoing incremental fiold change.

\section{Movement Permeability to Induce Incumbents into Collaborative Work}

The first task for movements striving for institutional change in organizational fields is to prompt reflexivo agency among institutionally enbedded incumbents (Greenwood \& Suddaby, 2006). Wo suggest that a movernent that is moderately structured is most likely to succeed in this task, as it is sufficiently structured to produce threats and market opportunities visible to field incumbents, while it is still permeable to their influonce.

In the case examined here, moventent structumation occurrod as independent activists in instigating roles becano embedded in local cliquos and began to coordinate their ideas and practicos, which led to the formation of a coherent cultural base around particular issues. With the emergence of these relational and cultural structures, the issue of sustainable tourisn became visible to field incumhents and other audiences, oxposing threats and inarket upportunities. A legitinacy threat was created by the movement's critique of industry practices, as wore sustainable tourism models, which made the incumbent industry look unsustainable. The threat of a flight tax was created when the Advisory Council drew on the Planet clique's cultural discourse in its critical 1994 report. Conversely, instigators' cxperimentation with. and commercialization of, sustainable tourism ideas provider valuable research and development on alternativo practices for field incumbents, revealing narket opportunities. The simultaneous creation of threats and market opportunities motiveterl field incurnbonts to reflect on sustainable tourism. while the franmented nature of the movement enabled them to try to influence the movement.

To explain how movement fragmentatiun enables incumbent agoncy, we draw on the concepts of "tight coupling" and "pormeability" from institutional theory (Groenwood \& Hinings, 1996: 1029, 1030). We define movement perneobility as tho extent to which a movement is structured, featuring a highly elaburated collective ackion frame. consensus around the movement's issues and practices. accepted relationships and status hierarchies. and strung social controls. all affecting the dogree to which nutsiders can penetrate the movement. In our caste, the disparate discourses and practices of Poople and Plenot allowed room for incumbents to influence the issuets meaning. Movenent leadership remained open, as neither clique was ahle to impose its franue or practices on the industry. Although the liramentation hampered the movement from achieving widespread change, it allowed incumbents to engage with the movement. Peripheral four operators began to collaborate with instigators, and elite tour operators supported several sustainable tourism campaigns. More importantly, the trade association ANVR engaged with the novement by chairing the multistakeholder platform IDUT. This observation is salient, as it contrasts witli the familiar story of movements ereating highly structured and strongly oppositional coller:tive action frames (Benford \& Snow. 2000) using a "common encmy" to mobilize and unite activists in cohesive networks. Faring such criticism, incumbents have no other option than to engage in "de!funsive institutional wurk" (Maguire \& Hardy, 2009), "boundary bolstering" (Zietsma \& Lawrence, 2010), and countermobilization (Honsmans, 2003) to safeguard the field's legitimacy.

To explain movement efficacy, social movernent scholars have thus far far:used on political opportunity structures (McAdam ot al., 1996) and corporate or industry opportunity structures (King, 2008: Raeburn, 2004: Schurman, 2004: Suule, 2009). which are external to the movement. Movement perncability instead refers to the movement's in. tomal opportunity structure. In vur case, the movement was moderatcly permeable, making threais and market opportunities recognizable to fiold incumbents while leaving the movement open to iucumbent influence. Movemonts are likely to be moderately perneablo when issues are multifaceted or emerging or when a broad goal exists but there arc multiple: or anbiguous means to achiere it. By contrast. when movements have clearly defined colloctive action frames and ostablished relational structures, they are less suscoptible to external influence. For instance, Rav suggested that microlsewers croated a strung collective identity that "inoculated" them against the threat of incumhent interference (2009: 63), excluding the possibility of collaboration with incumbents as microbrewers carved out an independent niche. Similarly, tumperanco supporters produced "a hostile normative environment" for hreweries (Hiatt, Sine, \& To!bert, 2009: 641), making compromise unlikely. Likewise, Weber of al. suggested that the biodynamic farmer movemont likely failed because its frame was formed arumed "powerful cultural codes" and "an elahorate set of practices" that 
lacked the "flexibility and inclusiveness that [would] allow a broader coalition to join" (2008: $560)$. At the other extreme, when muvements are too permeable, they are insufficiently organized to present threats and market opportunities to their targets, as was the case for independent retailers fighting against chain stores (Rau, 2009). As movement permeability focuses or the opportunity structure internal to nuvenents, we suggest it is a promising concept to understand the motivating and enabling dynamics undergirding the emergence of collaborative work between movements and fields.

\section{Collaborative Work and the Risk of Movement Cooptation}

Although the creation of threats and market opportunities may motivate incumbents to work with the inovement, and movement permeability may enahle then to do so, incumbents may not always want to change. They may collaborate with activists only with the intent to hring "the interests of a challenging group into alignment with [their] own goals" (Trumpy, 2008: 480), aod this collaborative work inay consequently "shade into cooptation" (Davis, Morrill, Rao, \& Soule, 2008: 391). Fieldgoverning bodies like trade associations are partictularly likely to attempt to manipulate challenger groups whon their memhers' positiuns and activities are threatened (Oliver, 1991). However, cooptation need not always work. Our findings suggest that attempts at movemenl cooptation can be deflected whon multiple actors engage in cultural and relational brokerage between the movement and the field. Such distributed hrokerage further increases the cultural and relational costructuration of the muvement with the field, and through this costructuration, cooptation hecomes nututual.

In this case, ANVK attempted cooptation hy participating in the movement and using the movement's discuurse and practices (cf. Coy \& Hedeen, 2005). As a field-governing body, ANVR's main motive to chair the IDUT platfurm was to maintain industry control over the pace and direction of the change procoss. ANVR also attempted cooptation through cultural brokerage: it adopted the movement's language in its 1998 public hrochure and launched the POEMS template in 1998, which signaled cultural reorientation but did not require substantive changes in material tarms. ANVR's cooptation attempt turned out to be fragile, however, as ofler incumbents and activists also entered the movement's permeable opportunity structure. For instance, Marvin, who was hired by Travel Abroad as an environmental manager, used network brokerage to uccupy a central position in the movement and claim a green image for the clite firm. Movement nember Pam also acted as a network broker by organizing a conference to bring together the People and Planet cliques as well as movement and industry members. Rather than fending of the movement's threat to the field by conpting it, ANVR itself became partly coopted as the movement's and field's cultural and relational structures became increasingly linked through hrokerage, leading to a more elahorate POEMS template and a small-world network. We thus observed mutual cooptation, a process by which two ог more groups attempting to influence each other through multiple interactions hecome emhedded in and shaped by the meaning system and sucial structure they cocreate.

While our study supports the risk of cooptation in collaborative work, we highlight the mochanism of distributed brokerage in deflecting this risk. Supporting simulation research by Buskens and van de Rijt (2008), our findings suggest that field meinbers are unlikely to gain the coopting control advantage they seek when multiple actors enter the same structural (Burt, 1992) and cultural holes (Pachucki \& Breiger, 2010) in a movement. In such situations. as shown in our case, coopting agents may become coopted themselves in the network and value frame they help to create through their actions. Counterintuitively. our findings suggest that a field's attempts to coopt a movement inay, in fact, be beneficial to the movement if distributed brokerage occurs. Atracting a field's cooptation efforts may simply he the first step toward collaborating. As such. our study provides a more nuanced understanding of the assumed power of incumbents in their privileged access to material, cultural, and political resources to "coopt," "absorb," or "undermine" actors who threaten the field's status quo (Fligstein \& McAdam, 2011: 15). Cooptation is not a "grand plan" designed by fjeld incumbents but an emergent and evolving process (Coy \& Hedeen. 2005: 409). We found that both the movement and the field experience different degrees of cooptation over time, as heterogeneous actors respond to and influence one anuther's beliefs, desires, practices. and opportunities through their behavior.

Viewing cooptation as emergent yields jnsight into tbe motives and actions of the coopting incumbent: in our case. the trade association ANVR. Pro- 
fessional, industry, and trade associations typically play conservative and defensive roles in organizational fiolds thruugh their channels of communica* tion, education, and monitoring (Greenwood st al., 2002; Vermeulen, Büch, \& Greenwood, 2007). These agencios protect their nembers interosts when facing legitimacy crises stimulated by social movement ofganizations (Bansal \& Roth, 2000; King \& Lenox, 2000). However, contrary to the pattorn described in the extant literature, ANVR oventually acted agoinst its widor membership base to take a leading nole in pushing for change desircd by the movement, even though it initially intended to jrotect its membors from movement interference. Wo suggest that the inotivation for ANVR's innovative actions can be explained by the process of mutual cooptation, while its ability to cleviate from its monbers' intorosts can bo explained by resource depenásenco (Pfeffer \& Salancik, 1978). Greenwood and Suddahy have argued that positions that hridge networks lessen "institutional cmbeddedness by exposing actors to institutional incompatibilitics, increasing their awareness of alternatives" (2006: 38 ). Yet, in this case, the disembedding of ANVR from the field scemed to matter less than its embedding in the evolving cultural and relational structures of the movement. Participation in crafting policies is well known to increase "ownership" of even unsatisfactory pulicies among movements (Coy \& IHedean, 2005), and this principlo also seemed to apply to ANVR. Furthermore, the relational honding between ANVR and movement members inotivated ANVR to innuvate upon the sustainahle tourism issuc. Yet, as memhership organizations, trade associations may lose credibility if they are not responsive to their nembers' interasts (Winn, Macbonald, \& Zietsnia, 2009). In this case, ANVR was protected from member backlash by its powerful consumer brand; its tour-operator members depended upon ANVR's label for legit:macy in the markot. Thus, whereas ANVR was conpted by the novement, not all incumbents so coopted would have the ability to choose to conform to the movement over tho field and advance the movement's position among their constituents.

\section{The Consequences of Mutual Cooptation: Ongoing Incremental Field Change}

Our findings provide new insights into moveinent cooptation. Interpreting the literature, wo might expect cooptation to result in the erosion of the movement. Polarization may occur between ac- fivists who view the collaborative work with incombents posifively and those why bolieve it is a sign of "selling out" moverucht itleals (Térrow, 1998;, stitling movemunt activity as energy lilows toward resolving the intornal conllick. Moreover, activists dissatisfied, remoralized, or disillusioned with results achicvod may wilhdraw their anergy, skills, and cxperience lion the movoment (Gantson. 1990). Conversely, those in favor of collaborative work may fail to either push for ahanges or bo sufficiently critical, hecause they want to maintain the acceptance of a field (Trumpy, 2008). In withor case, movoment activity wili docline and have little impact on the field undor challenge. In our case, we observed. instead. an increase in nubilizing capacity and energy as new nombers entered; the pace of innovation acceleraled, and a sustained period of innovation began, althougl this innovation was less radical than the novement initialy envisioned. We suggest that the conflutruce of cultural and relational structuration between the movemont and tho field genorated this tipping point and was responsible for the ongoing, incremental fitald change that wo observed through three innovation outcomes: accelerution, dilution of radicahoss, and jorsistence.

The pace of innovation accelerated for several rorsons. First, the POEMS templata oflered cloar guidolines for sustainable tourism, reducing uncertainty and revealing opportunitios lou existing and new instigators and brokers. The POEMS structure itself was critical; it was not a fully olaborated solution that closed off other uptions, but. insterd. its central coordinating strumturo unabled individ. uals to work relatively autonomously and still have their work cumulale effectively (cf. Bonaccorsi \& Rossi, 2003). In this sunse. POFMS was a platforn for modular innovation, sinnilar to opun-source projects like Limux and Wikipexdia." Secund, the pace of innovation was accelerated by the smallworld retwork structure, which allowed for the rapid circulation of now ideas and practices. connected potential partnors. made: opportunities recognizable, and attracted and absorbod new entrants who believed that change was within reacli. givant the involvement of lead incimbents. Third. the diffusion of innovations was rapid because the small-world network facilitated informatinn flow,

\footnotetext{
"We thank an anonymats reviower for" protuling nut the similarities between bur case and open-source projects.
} 
and the fit of innovations with POEMS (and, thus, tour-operator expectations) made diffusion easier.

Similar factors contrihuted to the dilution of the radicalness of innovation. The POEMS template conveyed information ahout what would be considered feasible by the field, while the small-world network allowed for the rapid diffusion of this information, making instigators constrain their creative work accordingly and attracting more prag. matically oriented entrants. Both structures also created a "cozy club" that contributed to dilution, as activists were unwilling to pose unrealistic demands for field change and criticize the progress made so far for fear of violating emerging social norms.

At the same time, with activists' more radical aims coopted and diluted, the movement attained new relevance for the field, resulting in the persistence of innovative action. The dominant template and small-world network ensured that novement and field nembers were receptive to each other's ideas and motivated to sustain their relationships, generating positive energy and facilitating the launch nf new projects in which innovations would he fine-tuned (and, thus, de-radicalized) in free discussions with field incumbents. In sum, the joint culture and network developed by the movement and the field amplified each other, creating dynamic effects that accelerated the pace of innovation, diluted its radicalness, and contributed to its persistence.

Movement cooptation is generally seen to have negative consequences for the movement's mohilizing capacity to accomplish field change; however, our study challenges this assumption by revealing an example of mutual cooptation as movement and field participants negotiated cultural structures and created a small-world network that significantly impacted their innovative outcomes. In our case, the template not only was introduced by a lead incumbent carrying the field with it hut also offered an open, flexible structure that attracted new entrants and energized extant movement members. Yet the template's success also depended on the movement's relational structure. The small-world network was open enough to allow new entrants, ideas, and practices, and it helped to coordinate distrihuted agency from the cliques up to the collective level, providing the opportunity to align innovations with field norms. Thus, it was the joint influence of the flexible caltural template and the snall-world network that created the conditions for the ongoing, incremental innovation we observed.
Overall, then, there are several pathways for movements to affect organizational fields. Sonte movements may maintain a purist ideology that maintains incumbents as critical enemies (Hoffman, 2006), but these movements risk becoming irrelevant as the field under challenge resists change and movement energy eventually subsides (Gamson, 1990; Tarrnw, 1998). Other movements may attempt to collaborate but become cospted, with iittle change resulting (Trumpy, 2008). Stili others may develop organizational structures that maintain the houndaries between the opposing groups and only allow them to collahorate on particular issues or projects (O'Mahony \& Bechky, 2008), limiting opportunities for creative work and member recruitment. Our study identified a different pathway, involving collaborative costructuration of movement and field to enable ongoing, incremental innovation.

\section{CONCLUISIONS}

We began this article by highlighting that institutional change in organizational fields is frequently the outcome of collective action involving social movements. We focused specifically on examining how collaborative work between independent activists and field incumhents emerges and changes the organizational field under challenge. Drawing on an intensive case study of the sustainable tourism movement in the Dutch outbound tour operations field from 1980 to 2005 , we illustrated how a movement's permeability induces field incumbents to engage in the movement. We further showed how field incumbents' attempts at muvement cooptation can actually help. rather than constrain, a movement in impacting the field when distributed brokerage occurs and contributes to mutual cooptation and the confluence of cultural and relational costructuration hetween movernent and field.

A primary contribution of our study, therefore, is its focus on the opportunity structures of movements by introducing the concept of movement permeability. This concept complements extant social movement studies that emphasize opportunity structures external to movements to explain movement efficacy in affecting organizational fields. Our study suggests that movements operate as a field, or a system of cultural and structural relations, rather than as an aggregation of actors, events, and actions, as is the more usual view of social movements in the literature (Diani, 2013). By drawing on 
the notion of permeability from institutional theory to understand the interactiun between movement and field, we contribute to the emerging cross-fertilization between social movement theory and institutional theory (Hargrave \& van de Ven, 2006; Rao et al., 2000: Schneiberg \& Lounsbury, 2008) and take an important step toward developing a more general theory of fields (Beckert, 2010; Fligstein \& McAdam, 2011). Моте specifically, our study uncovers the dynamic process by which two fields come to overlap (Evans \& Kay, 2008).

Moreover, we highlight the mechanism by which attempts at movement cooptation by field incumbents can, counterintuitively, advance a movement's mobilizing capacity tn impact the ficld under challenge. Our study illuminates how distributed brokerage may linit the ability of individual fie]d incumbents to direct the movement's evolution through conptation, while it may yield beneficial collective outcomes hy activating a process of mutual cooptation (cf. Iharra, Kilduff, \& Tsai, 2005). Uncovering this mechanism advances insights into the little understood phenomenon of movenent cooptation (Soule, 2009).

Finally, although social network theorists have recognized that social networks are culturally constituted (Emirbayer \& Goodwin, 1994; Owen-Smith \& Powell, 2008; Pachucki \& Breiger, 2010), оur sturly is al first attempt at empirically examining the interplay uf agency. culture, and networks uver time. This unique approach allowed us to examine the consequences of nutual cooptation for institutional imovation, noting how the cultural template and small-world network jointly created by movement and field members shaped the pace, degree, and persistence of imnovative activity. We assert, how'tver, that our study of egency, culture, and networks provides more than an empirical contribution; it yields ncw theoretical insights intu the contingencies affecting small-world network outcomes that would otherwise remain invisible to the analyst. Whereas Gulati et al. (2012) suggested that the formation of bridging ties in a network reduces entreprenteurial opportunities over time as it homogonizes the resource pool, our findings instead illustrate that opportunities for entrepreneurial agency may continuc to increase when small-world networks share a dominant, yet flexible cultural template. Whether field-level cultural templates merely cxtond the duration of small-world benefits or create pomanent benefits is an interesting topic for future study, as is the influence of distinct cul- tural tensplates on notwork development and outcomes.

Our study has limitations. As a service industry offering travel experiences as intangible products, the outbound tour operations field may be rather idiosyncratic. Yet we believe that the phenomenon we studied--collaborative work between challengers and defenders resulting in increnental ficld change-is not uncommon in practice but can be difficult to observe and research, as these processes do not feature the dramatic, punctuated-equilibrium shifts from "the old" to "the new." By studying this process closely, we believe that we have contributed to naturalistic: gencralizability, which enables insights to be applied to similar cases [Stake, 1995), and analytical generalizability, which allows for the broadening of theorios (Yin, 2003).

We identify four boundary conditiuns under which we expect the theory put forward in this article to hold. First, the movement's issue is likely to influence the interplay botween movement and field (Bansal \& Roth, 2000). Sustainable tourism is an ambiguous issue with impacts that are difficult to measure and attribute, and tradeoffs among social and environmental goals. Ambiguous issues allow more room for external influence on the issue's social construction, providing options for in. cumbent involvement. Futurc research should examine other characteristics of issucs and how these impact the potential for collaborative work. For instance, moral issues. like the right to aburtion. will be perceived as less ambignous because of activists' more hardened positions. reducing permeability and limiting the possibility of collaboration. Second, a movement's strength is likely to affect its use of the collaborative action modol. For example, nnore adversarial stances were takon by the anti-biotech movement, wbich was supported by market forces (Schurman, 2004), and the environmental movement fighting the chomical industry, which was supported by legal and govornmental pressures (Hoffman, 1999). In our cáse. external support was unavailable, increasing the nuovement's need for collaboration to achicve its goals. Future research should examine whether and how collaboration can emerge wben movements are in a position of strength. In addition to market and govermmental backing, Elsbach and Sutton (1992) suggest that a movement's strength deponds on movement composition and task division. Radical groups can provide the thrcutening impotus for organizational fields to contimue to expand their con- 
mitnents to the movement's cause, whereas reformist groups can help fields dovelop their commitments. This idea merits further research. Third, for collaboration to succeed in our casc, an incunbent partnes had to exist with the power and anthority to interar: with the novement and influence the ficld accordingly. ANVR was in this position. In other fields, field-governing bodies may not have the strength to engage in collaboration without their members' modorsements and may thus obstruct collaborative work. Further research is roquired to detemine whether other olite incumbents can assume this role or whether the role of a ficld-governing body is somewhat minue. Fourth, movement activism was, in our case, comprised of theorizing and founding events. Which not only ireated a discourse for chango but also ready-made proctices and oxperiential knowledge for field incumbents. At the same time, movements also pursue lagal challenges to forge chango (Hoffinan, 1999). Further research is warranted to determine how the movement's artivity portfolio influences tht inducemenl of field momhers into collahorative work. Thus, the degres of issue ambiguity, the strength of both the movement and the incumbont broker, and the portfolin of movement activities may influence the emergence and outcomes of collahorative work. Only further research can establish the generalizability of our findings.

This study has shown how a relatively unorgarsized movement with limited poiver, resources, and support was able to instigate thange in an estah lishod organizutional field, even when elites in the field wero attempting to dofuse the movement through cooptation. Uur sesults show the power of shared relationships and culture to change the way actors think and act, and to change the opportunities oper to then. Whereas the literature has typically emphasized efforts by movements to impose constraints on organizational lields and by incurnbents to block the entry of new actors, ideas. and practices into their field. we saw, in this case, the stimulating effects of looth activists' and incumbernts' fgency and innovations on field evolution, as relations and ideas flowerl frocly through jointly created structures and generated energy for change. Given the myriad of social problems the world faces that require collective action, such as persistent poverty, loss of biodiversity, and climate rhange. we need to know more about the enabling effocts of collaboration. The present work takes an important step in this direction.

\section{REFERENCES}

ANVR. 1996. Reiswereld en de zorg voor het milieu [The travel industry and caro for the envirumment]. De Meerm: Algemeen Nedorlands Verbond voor Reisondernemingen.

Baldassarri. D.. \& Diani, M, 2007. The integrative power of civic nctworks. American Journal of Sociology, 113: 735-780.

Bansal, T., \& Roth, K. 2000. Why companios go green: A model of ccological rosponsiveriess. Acodemy of Management Journal, 43: 717-736.

Bartley, T. 2010. 'Iransnational private regulation in practice: The limits of forest and labor standards certification in Indonesia. Business and Politics. http://www. bepress.com.hap/vol z 2/iss 3/art7.

Battilana, J., Leca, B., Be Boxenbaurn, E. 2009. How acturs change inslitutions: 'lowards a theory of institutional emepreneurship. In 1. P. Walsh \& A. P. brief (Eds.), Academy of Manogement onnols, vol. 3: 65-107. Essex. UK: Ruutledge.

Baun, I. A. C., Shipilov. A. V., \& Rowlcy. T. J. 2003. Whare do small worlds come from? Industrial and Corporate Chunge, 12: 697-725.

Bockert, ]. 2010. How do fields change? The interrelations of institutions, notworks, and cognition in the dynąmics of markets. Orgonjzotion Studies, 31 : $605-627$.

Benford, R. D., \& Strow, IJ. A, 2000. Framing processes and social movements: An overview and assessment. In K. S. Cook \& J. Hagan (E'ds.). Annuol review of sociology, vol. 26: 611-639. Palo Alto CA: Annua? Reviows.

Berg. B. L. 2004. Qualitative research methods for the social sciences (5th ed.): 265-297. Boston: Pearson Lducation.

Bonaccorsi. A., \& Rossi, C. 2003. Why open source suftware can succcetd. Research Policy, 32: 1243-1258.

Burgatti, S. P., \& Everet., M. G. 1997. Network analysis of 2-mode data. Social Nelworks, 19: 243-269.

Borgatti, S. P., Everett, M. C. \& Freeman, [. C. 2002. Ucinet for Windows: Software for sucial networks analysis. liarvard, MA: Anulytic Technologies.

Burt, R. S. 1992. Structural holes: The social structure of competition. Cambridge, MA: Harvard University Press.

Buskens, V., \& van de Rijt, A. 2009. Dynamiss of metworks if overyone strives for structural holes. American Journal of Sociology, 114: 37 1-407.

Cov, P. G.. \& Hedeen, T. 2005. A stage model of socia] 
movement cooptation: Conmunity mediation in the United States. Sociological Quarterly, 46: 405-43.5.

C.reswoll. J. W., \& Millor, D. L. 2000. Determining validity in guatitative inquiry. Theory into practice, 39: $124-130$.

Dacin, M. T., Goodstein, J., \& Scotl, W. R, 2002. Institutional theory and institutional change: Introduction to the spocial research forun. Academy of Manogement Journal, 45: 45-57.

Davis, G. F., Morrill, C.. Rao. II.. \& Suule, S. A. 2008. Introduction: Social novements in organizations and markots. Adninistrutive Science Quarferly, 53 : $389-394$.

Divis, G. F., You, M., \& Baker, IV, E. 2003. The small world of the Arnericar corporatu elite, 1982-2001. Strategic Organization, 1: 301-326.

Uiani, N. 2013. Organizational fields and social movement dynamics, In J. vin Stekelenburg, C. Koggeband, \& B. Klandermans (Eds.). The future of sociul movement research: Dynamics, mechanisms and processes. Minneapulis: Iniversity of Minnesuta Prass: lurthonming.

Diani. M., \& McAdam. D. (Eds.). 2003. Social movements and networks: Relational upproaches to collective uction. Uxford, UK: Oxford University Press.

DiMaggio. P. J. 1988. Interest and agency in institutional theor'y. In L. G. Zucker (Ed.), Instilutional patterns and organizations: Culture and environment: 3-21. Cambridge, $\mathrm{MA}$ : Ballinger.

DiMugnio, P. J. 1991. Constructing an organizational ficld as al professional project: lis art nuseums, 19201940. In W. W. Powel] \& P. I. DiMaggio [Eds.). The new institutionalism in organizational analysis: 267-292. Chinago: Untwersity of Chichgo Press.

DiMnggiu, P. J., \& Powoll, WV. WV. 1983, The irun case revisitad: Institutional isomorphism and collective l'ationality in organizational fields. American Sociologicul Review, +8: 147-160.

Edmondsun. A. C. \& McManus, S. E. 2007. Methodological fit in management field research. Academy of Management Review, 32: 1155-1179.

Likingtun. J. 1997. Cannibals with forks: The triple bottoln line of 21 st century business. Oxford, UK: Capstone.

Elsbis:h, K. D., \& Sutton. R. I. 1992, Acquiring organizatiunil legitimacy through illegitimate actions: A marriage of institutional and impression management theories. Academy of Monogement Jaurnal, 35: $699-738$.

Emirbaytr, M., \& Goodwin, 1. 1994. Notwork analysis, culture, and tho problem of agency. American Journal of Sociology, 99; 1411-1454.

Fvans, R., \& Kay, T. 2008. How environmentalists "greened" trade policy: Stratugic action and the architecture of field ovmlap. American Sociological Review, 73: 970-001.

Faust, K, 1997, Gentrality in affilialion retworks. Social Networks, 19: 157-191.

Fligstein. N. 2001. Social skill and the therry of fields. Sociological Theory, 19: 105-125.

Fligstein, N., \& Mc $\Lambda$ dim, D. 2011. Tuward at gemeral theory of strategic action fields. Sociological Theory, 29: 1-26.

Frooman. J. 1999. Stakeholder influmat stratggies. Academy of Management Heview, 24: 141-205.

Gamson, W. A, 1990. The strategy of social protest (2nd ed.]. Belmont, CA: Wadsworth.

Garud, R, Jain, S., \& Kumaraswamy, A. 2002. Institutional entrepreneurship in the sponsorship of common technological standards: Tho cast of Sun Microsystems and Java. Academy of Management Journal, 45: 196-214.

Garud, R. \& Rappa, M. A. 1994. A socio-rognitive model of technology evolution: The cass of cochlear implants. Organization Science, 5: 344-762.

Gibbert. M.. Ruigrok, W., \& Wicki, B. 200B. What passes as a rigorous cese study? Strategic Management Journal, 29: 1465-1474.

Greenwood, R., \& Hinings, G. R. 1996. Understanding radical organizational change: Bringing together tho old and the new institutionalism. Academy of Management Review, 21: 1022-1054.

Greenwood, R., \& Suddaby, R. 2006. Institutional ontrepreneurship in mature fields: Tho Big l'iva accound ing firms. Academy of Manogement Journal. 49: $27-48$.

Greenwood, R., Suddaby. R., \& Hinings, C. R. 2002. Theorizing changa: "The role of professional associations in the transformation of institutionalized fields. Academy of Management Journul, 45: $.88-80$.

Gulati, R., Sytch, M., \& Tatarynowicz, A. 2012, 'The rise and fall of small worids: Exploring the dynamirs of social structure. Organization Science, 23: 419471 .

Hardy, C.. \& Maguire, S. 2008. Institutional untreprenewsship. In R. Greenwroot, C. Oliver, K. Sahlin. \& R. Suddaby (Eds.). Handbook of orgonizational institutionolism: 198-217. Thousand Oaks, GA: Sage.

Hargrave. T. I. \& var de Von, A. H, 2006. $\Lambda$ colloctive 
action model of institutional innovation. Academy of Monagement Review, 31: 864-888.

Hensmans, M. 2003. Social movement orghnizations: A metaphor for strategic actors in institutional fields. Organization Studies, 24: 355-381.

Hiatt, S. R., Sine, W. D., \& Tolbert, P. S. 2009. From Pabst to Pepsi: The deinstitutionalization of social praclices and the creation of entrepreneurial opportunilies. Administrative Science Quarterly, 54: 635667.

I Ioffman, A. J. 1999. Institutional evolution and change: Envirommentalism and the US chemical industry. Academy of Management Journal, 42: 351-371.

Hoffman, A. J. 2006. Cooptation or corvergence in field level dynamics: Social movement structure, identity and image. Ross School of Business Paper No. 7037. Available at SSRN: http://ssm,com/abstract= 927032 or dui:10.2139/ssm.927032.

Iberra, H.. Kilduff, M., \& Tsai, W. 2005. Zooming in and out: Connecting individuals and collectivities at tho frontiors of organizational network research. Orgonization Science, 16: 359-371.

[ick, T. D. 1979. Mixing qualitative and quantitative metbods: Triangulation in action. Administrative Science Quarterly, 24: 602-611.

King, A. A., \& L.enox, M. J. 2000. Industry self-regulation without sanctions: The chemical industry's Responsible Care Program. Academy of Management Journal, 43: $698-716$.

King, B. G. 2008. A social movenent perspective of stakebolder collective action and influence. Business and Society, 47: 21-49.

King, B. G. \& Pearce, N. A. 2010. The contentiousness of markets: Politics, social movements, and institutional change in markets. In K. S. Cook \& D. S. Massey (Eds.), Annual review of sociology, vol. 36 : 249-267. Palo Alto, CA: Annual Reviews.

Kugul, B., \& Walker, G. 2001. The small world of Germany and the durability of national networks. American Sociolagical Review, 66: 317-335.

Krippendorf, ], 1975. Die Landschafisfresser: Touris. mus und Erholungslandschaft-Vererben oder Segen? [The devourers of the countryside: Tourism and recreation landscape-curse or blessing?]. Bern: Hallwag.

Langley, A. 1999. Strategies for theorizing from process data. Academy of Management Review, 24: 691710 .

Langley, A. 2007. Process thinking in strategic organization. Strategic Organization, 5: 271-282.
Lawrence, 'T. B., \& Phillips, N. 2004. From Moby Dick to Free Willy: Macro-cultural discourse and institutional ontrepreneurship in omerging institutional fields. Organization, 11 : $689-711$.

Lounsbury. M. 2001. Institutional sources of practice variation: Staffing colloge and university reryeding progrims. Administrative Science Quarterly, 45: $29-56$

Lounsbury, M. 2005. Instilutional rariation in the evolution of social movemests: Compoting logics and the spread of recycling advocacy groups. In G. F. Davis. D. McAdam, W. R. Scotl, \& M. N. Zald (Eds.), Social movements and organization theory: 73-95. Cat11m bridge. UK: Cambridge Iniversily Press.

Lounsbury, M., Ventresca. M. J., \& Hirsch, P. M. 2003. Social movements, field frantes and industry enorgence: A cultural-polilical perspectivo ur US recycling. Socio-Economic Review, i: 71-104.

Magujro, S., \& Hardy, G. 2009. Discourse and deinslitutionilization: The decline of U.T. Academy of Manggement Joumal, 52: 148-178.

McAdam. D., McCarthy. J. D.. \& Zuld. M. N. 1996. Comparative perspectives on social movements: Political opportunities, mobilizing structures, and cultural fromings. Now York: Cambridge Uuiversity' Press.

Mever, A. D. 1982. Adapting tu environmental jolts. Administrative Science Quarterly, 27: 515-537.

Munir, K. A. \& Phillips, N. 2005. The bisth of the "Kodak moment": Institutional motreprenturship and the adoption of new technologies. Organization Studies, 26 : 1665-1687.

O'Grady, R. 1981. Third world stopover: The tourism debote. Geneva: World Council of Churches.

OMahony, S., \& Bexhky, B. A. 2u08. Boundary organizatjons: Enibling collaboration among unexpected allies. Administrative Science Quarterly, 53: 422459 .

Obstfeld, D. 2005. Sncial netwurks, the tertits iungens orientation, and involvenent in innovatiun. Administrative Science Quarferly, 50: 100-130.

Oliver, C. 1991. Strategic: responses to institutional processes. Acodemy of Monogement Review, 16: 145179.

Owen-Smith. J., \& Puwell, W. W. 2008. Networks and institutions. In R. Gremwoud, C. Oliver, K. Sahlin, \& R. Suddaby (Eds.), Handbook of organizational institulionalism: 596-623. Thousand Oaks, CA: Sage.

Pachucki, M. A., \& Breiger, R. L. 2010. Cultural holes: Beyond relationality in social networks and culture. In K. S. Cook \& D. S. Massuy (E.ds.), Annuwl review 
of sociology vol. 36: 205-224. Palo Alto, CA: Annual Reviews.

Pfeffer. J., \& Snlancik, G. R. 1978. The external control of organizotions. Nuw Yurk: Randorn Hause.

Phillips, N., Lawrence, T. B., \& Hardy. C. 2000. Inter-organizational collaboretion and the dynamics of institutinal fiolds. Journal of Management Studies, 37: $23-43$.

Podolny, J, M. 2001 . Networks as the pipes and prisms of the market. Americon Joumal of Sociology, 107: $33-60$.

Proyun, K. G.. Fish, $A$. , Sydow, J. 2007. Interorganizational notworks at the retwork level: $A$ reviow of the ompirical literature on wholo networks. Journal of Management, 33: 47 $\mathrm{y}-516$.

Provan. K. G.. \& Sebastian, 1. G. 1998. Networks within motworks: Survirat link overlap. organigational cliques, and network effectivenoss. Academy of Management Journal, 41 : 453-463.

Raeburrl. N. C. 2004. Changing corporate America from inside uut: Lesbion ond gay workplace rights. Minn ncipolis: University of Minnesota Press.

Riu. J]. 2009. Market rebels: How activists make or break radical innovations. Princeton, NJ: Princeton University Press.

Rars. H.. Morrill, C., \& Zald, M. N, 2000. Power plays: How sorial movements and collective aclion creato ncw organizational forms. In B. M. Staw \& R. L. Sutton (Eds.), Heseorch in organizational behavior, vol. 22: 237-281. Greenwich. CT: JAI.

Ring, I’. S., \& van de Ven, A. H゙, 1994. Developmental processes of cnoperative intororganizational relationships. Academy of Management fleview, 19: $90-118$.

Rowley. T. J.. Grevi, II. R, Rao, H., Baum, I. A. C., \& Shipilov. A. V. 2005. "Time to break up: Social and instrumental antucudments of firm, exits from exchatuge ciliques. Acudemy of Manogemenf Joornal, 48: $499-520$.

Schnetberg. M., Lounstury, M. 2008. Social movoments and institutional andysis. In R. Greenwood, C. Oliver, K. Sahlin, R R. Suddahy (Eds.), Handbook of organizational instifutianalism: 650-672. Londoul: Singe..

Schneilytrg. M., \& Sumis, S. A. 2005. Institulionalization as a contested. mulli-levnl process: Politics, social movonwrits and rate regulation in American fire issurance. In G. F. Jiuvis, D. McAdam, W. R. Socolt, \&
M. N. Zald (Eds.), Social movements and organiza* tions: 122-160. Cambridge, UK: Cantbridge University Press.

Schurman, R. 2004. Fighting "lrankenfonds": Industry opportunity structures and the efficacy of the antibiutech movement in Western Furape. Sorial Problems, $51: 243-268$.

Scott, W. R. 2001, Institutions and organizations (2nd ed.). "Thousand Oaks. C.A: Sage.

Scott, W. R., Deschenes, S., Hopkins, K., Nuwnau, A., \& McLaughlin, M. 2006. Advocaiy organizations and tho field of youth services: Ongoing efforts to restructure a field. Nonprofit and Voluntary Sector Quarterly, 35: 691-714.

Sine, W. D., \& lee, B. D. 2009 . l"Iting at windmills? The envirommental movement and the emergence of thi: IJS wind energy sector, Administrative Science Quarterly, 54: 123-155.

Smith, A. D. 2002. From process data to publicution: A personal sensemaking. Journal of Management Inquiry, 1]: 383-406.

Soutin, S. A. 2009. Contention and corporate social responsibility. Canbridge. UK: Cambridge IJniversity Press.

Stake. R. 1905. The art of case study research. Thnusand Oaks, CA: Sage.

Svejenova. S., Mazza, C., \& Planellas, M. 2007. Cooking up change in haute cuisino: Ferran Adria as an institutional entreprencur, Journal of Organizational Behaviar, 28: 539-561.

Tarrow, S. 1998. Pawcr in movement: Social movements and contentious politics (2nd ed.). Cambridge. UK: Can'bridge University Press.

Tepelus, C. M. 2005. Aining for sustainability in the tour operating business. Joumal of Cleoner Production, 11: $99-107$.

Trumpy. A. J. 2008. Stbject to negotiation: The morhanisms belind cooptation and corporate reform. Social Problems, 55: 480-500.

Tumer, L.. \& Ash, ]. 1975. The golden hordes: International toarism and the pleasure periphery. Lol]don: Constable.

Uzzi, B. 1997, Social structure and competition in inter* firm networks: 'The paradox of embeddedness. Ad" ministrative Science Quarterly, 42: 35-67.

Uzzi, B., \& Spiro. J. 2005. Collahoration and croativity: The small world prohlem. American Journal of Sociology, 11 1: 447-504. 
van de Pol, Y. 1999. Toerisme en duurzame ontwikkeling: Een wisselwerking verkend [Tourism and sustainable development: The interplay explored]. Amsterdan, the Netherlands: Nationale Commissie voor internationale samenwerking en duwzame ontwikkeling.

van de Ven, A. H. \& Poole, M. C. 2002. Field mesearch methods. In J. A. C. Baum (Ed.), Componion to organizotions: 867-888. Oxtord: Blackwell.

Vermeulen, P.r Büch, R., \& Greenwood, R. 2007. Thı impact of governmental policies in institutional fjelds: The case of innovation in the Dutch concrete industry. Organization Studies, 28: 515-540.

Wasserman, S., \& Faust, K. 1994. Social network analysis: Methods and applications. New York: Cambridge University $\mathrm{H}$ ress.

Walts, D. J. 1999. Networks, dymamics, and the smallworld phonomenon. American Jaurnal of Sociology, 105: $493-528$.

WCED. 1987. Our common future. Oxford, UK: Oxford University Press.

Weber, K., \& Dacin. M. T. 2011. The cultural construction of organizational life: Introduction to the special issue. Organization Science, 22: 287-298.

Weber, K., Heinze, K. L., deSoucey, M. 2008. Forage for thought: Mobilizing codes in the movement for grass-fed meal and dairy products. Administrative Science Quarterly, 53: 529-567.

Winn, M., MacDonald, P., \& Zjetsma, C. 2008. Managing industry reputation: The dynamic tension between collective and competitive reputation management strategies. Corporate Reputation Review, 1 : $35-55$.

WTO/OMT. 2002. Voluntary initiatives for sustainable tourism. Madrid: World Tourism Organization.

Yin. R. K. 2003. Case study research: Design and methods (3rd ed.). Thousand Oaks, CA: Sage.

Zictsma, C.. \& Lawrence, T. B. 2010. Institutiona] work in the transformation of an organizational field: The interplay of boundary work and practice work. Administrative Science Quorterly, 55: 189-221.
Mi

Jakomijn van Wijk (wijk@msm.n) is an assistant proftessor at Maastricht School of Management. She received her Ph.D. from VU Jniversity Amsterdm. Her research interests include institutional change in organizational fields, partnership networks in global velue chains, and (self-) governance for sustainable development. Sho currently examines conservation organizations that promot: tourism is a means to protect wildlife and combat poverty in Africa.

Wouter Stam (wstan@ust.hk) is an assistant professor at the Hong Kong University of Scimse ind "Technology (IJKUST). He received his Ph.D. from VU Univorsity Amsterdam and has boen a visiting scholar at thes Wharton School, Universily of Pennsylvania. His research interests include intra- and interurganizational networks, strategic entrepreneurship, and the emergonco of new industries and fields.

Tom Elfring (t.elfring@vu.nl) is professur of strategic management and entrepreneurship at the Faculty of Loonomics and Business Administration of VU University Amsterdam. He received his Ph.D. from the University of Groningen, ilis current research interests include nitworking in entrepreneurial ventures. corporate entrepretneurship, and managing service imnovation.

Charleue Zietsma (cziotsma@schulich.yorku.ca) is atl associate professor and the Ann Brown Chair of Orgarization Studies at the Schulich School of Business, York University. She received her Ph.D. from the University of British Columbia. Her research uses theories of jnstitutions, social novements, and entrepreneurs to investigate the agency and processes involved in social changt: efforts, particularly in the context of business ant? sustainability,

Frank den Hond (f.den.hond@vu.nl) is profossor of management and organization at Hanken School of Economics and an associate professor in the Department of Organizalion Science. Faculty of Social Scionces. VU University Amsterdam. He receivod his Ph.IJ. from VU University Ansterdam. His research interests are at the intersection of business in suciety, institutional organization theory, and sucial movement studies.

$M$ 
Copyright of Academy of Management Journal is the property of Academy of Management and its content may not be copied or emailed to multiple sites or posted to a listserv without the copyright holder's express written permission. However, users may print, download, or email articles for individual use. 